John Carroll University

Carroll Collected

Biology

$2-2014$

\title{
Biogeomorphology of a Mojave Desert landscape Configurations and feedbacks of abiotic and biotic land surfaces during landform evolution
}

Rebecca E. Drenovsky

John Carroll University, rdrenovsky@jcu.edu

N. Pietrasiak

L. S. Santiago

R. C. Graham

Follow this and additional works at: http://collected.jcu.edu/biol-facpub

Part of the Biology Commons

\section{Recommended Citation}

Drenovsky, Rebecca E.; Pietrasiak, N.; Santiago, L. S.; and Graham, R. C., "Biogeomorphology of a Mojave Desert landscape Configurations and feedbacks of abiotic and biotic land surfaces during landform evolution" (2014). Biology. 14.

http://collected.jcu.edu/biol-facpub/14

This Article is brought to you for free and open access by Carroll Collected. It has been accepted for inclusion in Biology by an authorized administrator of Carroll Collected. For more information, please contact connell@jcu.edu. 


\title{
Biogeomorphology of a Mojave Desert landscape - Configurations and feedbacks of abiotic and biotic land surfaces during landform evolution
}

\author{
Nicole Pietrasiak ${ }^{\mathrm{a}, *}$, Rebecca E. Drenovsky ${ }^{\mathrm{b}}$, Louis S. Santiago ${ }^{\mathrm{c}}$, Robert C. Graham ${ }^{\mathrm{a}}$ \\ a University of California, Riverside, Soil and Water Sciences Program, Department of Environmental Sciences, 2258 Geology Building, University of California, Riverside, CA 92521, USA \\ b Biology Department, John Carroll University, 20700 North Park Blvd. University Heights, OH 44118, USA \\ c University of California, Riverside, Botany and Plant Sciences Department, 3113 Bachelor Hall, University of California, Riverside, CA 92521, USA
}

Keywords:

Landscape ecology

Discriminant analysis

Canonical correspondence analysis

Biological soil crust

Community ecology

Landscape evolutionary trajectories

\begin{abstract}
A B S T R A C T
Terrestrial ecosystems can be more holistically understood by investigating the morphology of landscape mosaics, the assemblage of their ecological communities, and the linkages and feedbacks between the mosaics and communities. The overarching objectives of this study were to: (1) study the abiotic and biotic configurations of landform units as mosaics within a Mojave Desert chronosequence; and (2) elucidate their potential feedbacks, interactions, and dynamics during landform evolution. Seven landform units distributed over three geomorphic ages were identified, including: young bars and swales; intermediate-aged flattened bars, flattened swales, and bioturbation units; and old desert pavements and shrub zones. These landform units were characterized according to abiotic and biotic land surface properties. Landform units were statistically distinct and predictable based on a specific suite of abiotic and biotic properties. Vascular plant functional group and biological soil crust community diversity varied with geomorphology, with greatest diversity associated with bars and shrub zones and lowest diversity associated with desert pavements. Biological soil crust communities were controlled by geomorphic age, surface rock size, and protruding rocks with young bar units having the highest abundance and diversity. Perennial forbs were observed in old shrub zones with small rocks and few protruding rocks. A high clast density and a finer-sized clast distribution were found particularly in desert pavements and flattened swales, and generally inhibited biological soil crust and plant cover. Evolutionary trajectories for landforms of a lower piedmont landscape can be dominated by either abiotic and biotic landform processes. These two trajectories are distinctly different and are associated with their own unique linkages, feedbacks, and dynamics of abiotic and biotic land surface properties, producing a highly diverse desert landscape.
\end{abstract}

\section{Introduction}

Landscapes are composed of diverse but spatially distinctive and repeating mosaics of abiotic and biotic landscape elements. These patterns raise the key questions. (1) What are the factors that determine mosaic configuration in landscapes? (2) What structures ecological communities across these mosaic landscapes? (3) What are the feedbacks between biotic communities and landscape formation and development? Landscape ecologists and biogeomorphologists have made significant advances within the last two decades in addressing these questions (see Viles, 1988; Wainwright, 2009). However, research questions and statistical hypothesis testing are often limited by the complexity of the components and their interactions within the landscape (Wiens et al., 1993). As a result, researchers have often

\footnotetext{
* Corresponding author at: Biology Department, John Carroll University, 20700 North Park Blvd. University Heights, OH 44118, USA. Tel.: +1 216397 3077; fax: +1 216397 4482.

E-mail addresses: npiet001@ucr.edu (N. Pietrasiak), rdrenovsky@jcu.edu

(R.E. Drenovsky), santiago@ucr.edu (L.S. Santiago), graham@ucr.edu (R.C. Graham).
}

taken a reductionist approach by limiting questions to a specific taxonomic group or geomorphic process. This method often precludes the detection of emergent properties, multiple mechanistic explanations for patterns, and a holistic understanding of landscape processes (see Gaston and Blackburn, 1999; Lawton, 1999; Naylor et al., 2002). Also, abiotic and biotic properties of ecosystems may be tightly linked due to the feedbacks between biota and their environment that were not, or maybe even cannot, be directly measured (Lawton, 1999). Thus, studies that integrate methodologies from the fields of biogeomorphology and landscape ecology, and consider contrasting reciprocal interactions and feedbacks between multiple biotic and abiotic spatial phenomena, are needed (Naylor et al., 2002; Haussmann, 2011).

Desert landscapes can be model systems for such integrative landscape ecological and biogeomorphological questions. Desert ecosystems comprise about one third of the Earth's land surface, a significant portion of terrestrial ecosystems (Goudie, 2002), and their landscapes can be easily structured into geomorphic components, i.e. landforms. Characteristic landforms such as alluvial fans, dunes, and playas occur in deserts worldwide (Peterson, 1981). At a local scale, landforms are composed of units that vary widely in age and land surface properties 
(Peterson, 1981; Bedford and Small, 2008), thus representing strong gradients. These landforms also repeat in space, creating visually striking mosaics of physical land surface components including bare soil, gravel, rocks, and boulders; and biological components including vegetation and biological soil crusts (Dunkerly and Brown, 1995; Rietkerk et al., 2004; Dixon, 2009; Pietrasiak et al., 2011a, b). Unlike mesic environments, generally there are stark boundaries between biotic and abiotic landscape components. As a result, patterns and interactions between these components are easier to discern during desert landscape evolution. From a vegetation perspective, this patterning has been described as 'islands of fertility' at the local scale (i.e., shrub versus shrub-interspace, Schlesinger et al., 1996) and as 'tigerbush' or 'vegetation labyrinths' at the regional scale (see review by Rietkerk et al., 2004). These vegetation patterns are sufficiently predictable, based on environmental components, to be described by theoretical cellular automata models (Bailey, 2011). Overall, the stark patterning observed in deserts provides a unique opportunity to understand the processes and interactions between abiotic and biotic landscape components.

In the past three decades, there has been an increasing appreciation for geomorphic impacts on biota in arid and semiarid ecosystems. So far, most studies demonstrating the driving force of geomorphology have focused on vascular plants. For example, landforms associated with differing soil properties often produce contrasting plant communities (Parker, 1991, 1995; McAuliffe, 1994; Hook and Burke, 2000; Buxbaum and Vanderbilt, 2007; Bisigato et al., 2009). Geomorphicallyrelated factors also influence processes at the individual plant level such as root morphology (Gile et al., 1998), leaf and canopy characteristics (Mauchamp et al., 1993; Sponseller and Fisher, 2006), leaf water potential (Mauchamp et al., 1993; Hamerlynck et al., 2002), plant recruitment, and population dynamics (Mauchamp et al., 1993; McAuliffe, 1994; McAuliffe et al., 2007). Substantially less work has addressed the impact of geomorphology on animals. Most of this research has focused on habitat needs and patch occupancy, which generally are associated with spatial patterns of vegetation structure or land surface properties (Crawford, 1988; Gutzwiller and Barrow, 2002; Bradford et al., 2003). In addition, there is much to learn about how geomorphology influences desert microbial communities. Other researchers have started to look into micro- and mesoscale patterning of microbial communities (Liu et al., 2000; Aanderud et al., 2008; Ginzburg et al., 2008; Pietrasiak et al., 2011b) but the direct impacts of geomorphology on the ecology and physiology of soil microbial communities are less well understood. This research gap is of great importance, as soil microbial communities drive essential geomorphic and ecosystem processes such as biogeochemical cycling, bioweathering, infiltration, and erosion.

Just as geomorphic patterns and their associated abiotic factors influence biota, biota may act as drivers of geomorphic processes. For example, hydrological processes, sediment accumulation, and soil transformation all can be coupled to biological activity (Wainwright, 2009). Within the last two decades, there has been a greater focus on understanding how biota impact particular geomorphic processes in deserts. Much of this research has addressed the effects of vegetation on fluvial and eolian processes (Wainwright, 2009). Many studies have shown how individuals or stands of shrubs promote run-on, infiltration, and sediment trapping (e.g., Rostagno, 1989; Dunkerly and Brown, 1995; Neave and Abrahams, 2001; Hupy, 2004, and see review by Ludwig et al., 2005). Likewise, bioturbation by small and mediumsized mammals influences hydrological and eolian processes through burrowing activity, creating heterogeneous landscape structure. Mound building and tunneling can redistribute resources by trapping sediment and water as well as by enhancing the erosion and transport of soil loosened during burrowing activity (Alkon, 1999; Bangert and Slobodchikoff, 2000; Schooley and Wiens, 2001; Davidson and Lightfoot, 2008). At smaller spatial extents, microbial communities associated with biological soil crusts can influence both water and wind flow (Eldridge and Greene, 1994; Eldridge et al., 2002; Belnap et al.,
2007). Although we are beginning to discern ways in which biota influence geomorphic processes, little work has linked biota to landform evolution, especially over long timescales (centuries to $>1,000,000$ years).

Therefore, although previous research has helped discern how specific aspects of desert geomorphology influence specific groups of organisms (and vice versa), it still remains unclear how multiple landscape components interact and influence landform evolution. Thus, our overarching goal was to understand how multiple abiotic and biotic factors contribute to landscape patterning and evolution and what potential feedbacks and dynamics exist between these factors in a desert environment. To accomplish this aim we: (1) described landform units according to their abiotic (morphometric and physical) and biotic surface properties (biological soil crust communities and plant functional groups); (2) determined whether abiotic processes, biotic processes, or a combination of abiotic and biotic processes drive potential differences between landform units; (3) discerned whether landform units differ in plant functional group and biological soil crust community richness and diversity; and (4) determined which abiotic factors significantly drive the composition of biological soil crust and plant communities. We then used these data to describe two hypothesized landform trajectories over time.

\section{Materials and methods}

\subsection{Study site}

This study was conducted in the Clark Mountain Wilderness area, in the northeastern part of the Mojave Desert National Preserve, southeastern California, USA (ca. $35^{\circ} 30^{\prime} \mathrm{N}, 115^{\circ} 41^{\prime} \mathrm{W}$; Fig. 1a). The study area was located on the fan skirt of the lower piedmont slope. This landform is morphologically analogous to other piedmont landforms in the Mojave Desert, as well as those in the Sonoran and Great Basin Deserts.

Since the beginning of the Holocene, the climate in the area has been arid, mostly resulting from the rain shadow effect of the Cordilleran Mountain Complex (MacMahon and Wagner, 1985; Norris and Webb, 1990; Jannick et al., 1991; Koehler et al., 2005). Mean annual precipitation is $145 \mathrm{~mm}$, and mean annual temperature is $17^{\circ} \mathrm{C}$, adjusted for elevational difference using the NCDC Mountain Pass 1SE Meteorological Station (see Turk, 2012). Annual rain events are highly variable in time and space (Osborn, 1983). The precipitation is bimodal, with most precipitation falling in the winter months as mild rains or occasional snow events at high elevation mostly originating from the Pacific Ocean (MacMahon and Wagner, 1985). In late summer, monsoon thunderstorms from the Gulf of Mexico cause scattered summer pulse rain events. These localized rain events often quickly exceed the infiltration capacity of the soils, leading to rapid runoff and flash floods (Evenari, 1985; Miles and Goudey, 1997).

The geology of the Clark Mountain Range is highly complex. Proterozoic crystalline rocks are mixed with Paleozoic to Mesozoic sedimentary bedrock (Norris and Webb, 1990; Walker et al., 1995; Schmidt and McMackin, 2006; Hall, 2007). For this study, we selected a watershed with the bedrock and consequential alluvial deposits of the fan skirt being composed of mostly dolomite with minor amounts of limestone, to minimize site heterogeneity.

The soils on younger geomorphic surfaces of the piedmont have been classified as Typic Torriorthents and Typic Torrifluvents and on older surfaces as Typic or Durinodic Haplocalcids and Typic Haplocambids (Pietrasiak, 2012). The soil moisture regime for the study area is aridic, and the soil temperature is thermic (Miles and Goudey, 1997).

The watershed is characterized by patchy vegetation with characteristic shrub island/interspace micro-patterning, in which vegetation is restricted to 'islands' surrounded by relatively open space (Gallardo and Schlesinger, 1992; Schlesinger et al., 1996). Biological soil crusts typically are associated with the inter-shrub spaces and/or edges of shrub islands. The dominant vegetation on the lower piedmont is an 


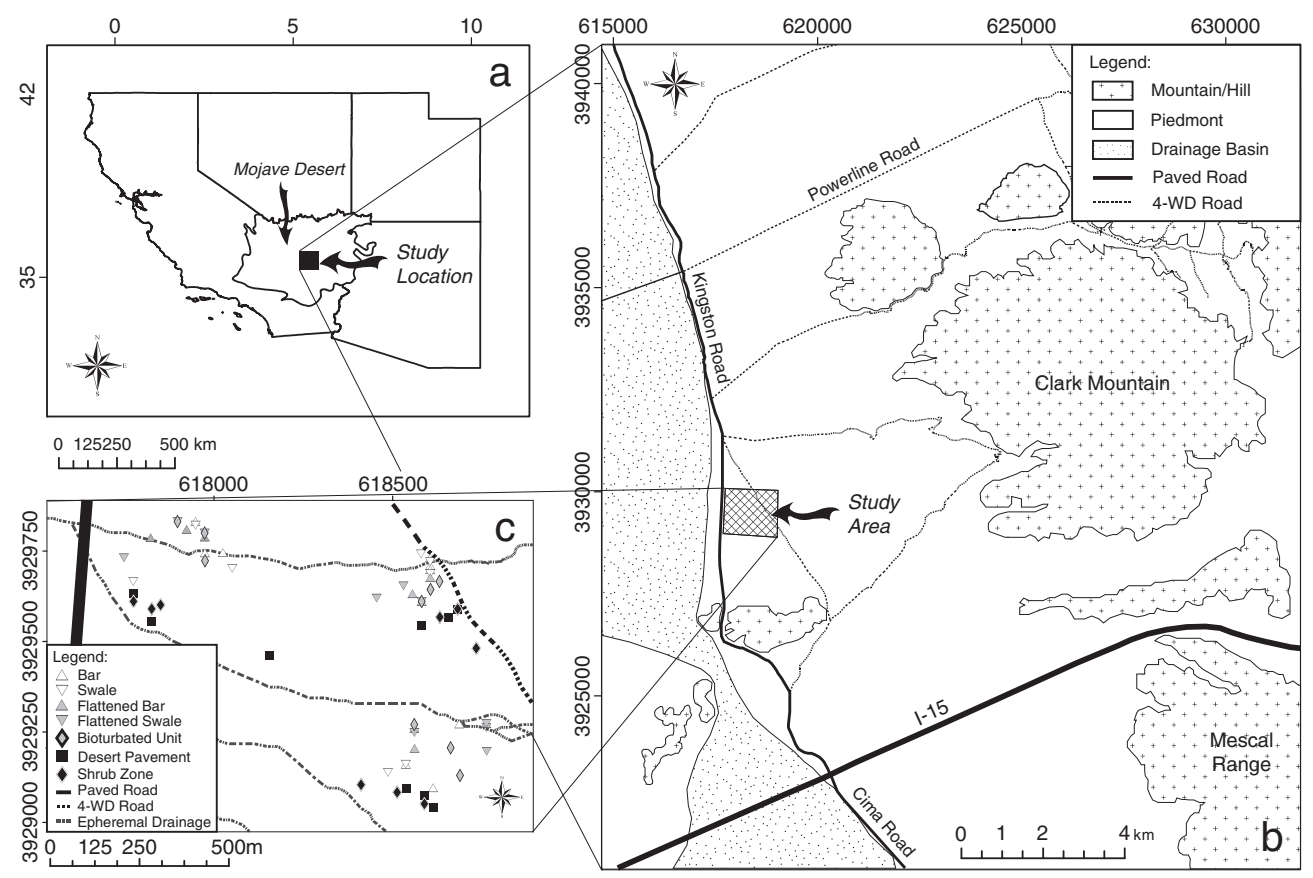

Fig. 1. Maps and spatial extent of the study area within the Mojave Desert of the western U.S.

association of the shrubs Larrea tridentata and Ambrosia dumosa mixed with Ephedra nevadensis, Yucca schidigera, Yucca brevifolia, and Krameria spp. Numerous annual plants grow in these areas following spring rains, but given their ephemeral nature, they were not included in this study, as our focus was on long-term patterning.

\subsection{Field sampling}

Using remote sensing coupled with field observations, geomorphic surfaces of three different relative ages on the fan skirt were identified. Initially, relative age determination was obtained by relating position and elevation of each surface to the active drainage (Birkeland, 1999; Watchman and Twidale, 2002). Accordingly, the young surface was composed of active washes and located lowest in the landscape. The intermediate geomorphic surface was slightly elevated and some distance away from the active wash. The oldest geomorphic surface was highest in elevation compared to the other geomorphic surfaces. Later, based on soil carbonate morphology, the young geomorphic surface was estimated to be 500 to 1000 years old, the intermediate geomorphic surface 4000 to 5000 years old, and the old geomorphic surface 10,000 to 50,000 (Pietrasiak, 2012). Within those three geomorphic surfaces, seven morphological types of mesoscale (10 to $100 \mathrm{~m}^{2}$ ) landform units were identified. Two units were found on young, three on intermediate, and two on old geomorphic surfaces. The selected units were easily recognizable and visually distinct, representing commonly occurring landform units within the entire Mojave Desert.

The two youngest units were the bar and swale units, which were found in active washes. They are associated with alluvial fan depositional processes. Bars were a deposit of coarse alluvial debris with a distinct convex-shaped ridge. Swales were found parallel to the bars. They were composed of fine alluvial debris deposits. In cross section, swales were distinctly concave-shaped with low microtopography. Both units were separated very easily due to a distinct unit boundary created by the visual contrast of adjoining coarse bar with fine swale alluvial debris.

The intermediate-aged units were classified as flattened bars, flattened swales, and bioturbated units. Flattened bars were covered by coarse alluvial debris comparable to the young bars. However, in cross-section the flattened bars were linear to slightly convex. Flattened swales were covered with fine alluvial debris and in cross section linear to slightly concave. Flattened bar and swale units were more difficult to separate from each other due to the diffuse boundary between the two units. The indistinct boundary was attributed to redistribution of debris materials. Bioturbated units had a large number of burrows created by small mammals such as kangaroo rats, pocket mice or ground squirrels. They were circular to ovoid shaped units with a distinct convex-shaped mound in cross-section and distinct unit boundary. On the land surface of these units, surface rocks (= clasts) and bare soil material appeared lighter colored compared to those on the adjacent surrounding flattened bar and swale units. The clasts in the bioturbated units had white pedogenic calcium carbonate coatings and were brought up from deeper calcium-carbonate enriched horizons by bioturbation (Eghbal and Southard, 1993; Pietrasiak, 2012). The bioturbation units were mostly associated with large Larrea tridentata shrubs.

The two units on the oldest geomorphic surface were classified as desert pavement and shrub zone. Desert pavements were barren, flat land surface units. The clasts were mixed, being composed of fine (gravel sized: 2 to $74 \mathrm{~mm}$ ) and large (cobble sized: 74 to $120 \mathrm{~mm}$ ) clasts. In contrast, the shrub unit was characterized by a relatively larger bare soil component and greater vegetative abundance. This unit was interspersed with the desert pavement units. In general, it had a slightly convex topography which contrasted with the linear surface of the desert pavement.

Within a $2 \mathrm{~km}^{2}$ area (Fig. $1 \mathrm{~b}$ ), $\approx 210$ landforms representing each of the seven landform units (bar, swale, flattened bar, flattened swale, bioturbated unit, desert pavement, shrub zone) were spatially located with GPS coordinates (minimum of 30 landforms per type). Out of this pool of landform units, nine replicate landform units per type were randomly chosen (total of 63 studied landform units selected from the original pool of 210 identified landform units, Fig. 1c). These landform units were used to characterize land surface properties (morphometric, physical, and biological). Characterization occurred between July and September 2009 for three representative landform units of each type and January and April 2010 for the remaining six replicates per type. Morphometric land surface properties included the profile and cross section shapes of the landform units and its areal extent (Table 1). Landform unit shape was categorized as: linear, convex, slightly convex, concave or slightly concave (Schoeneberger et al., 2002). The length and width of the studied landform units were measured and the area was estimated using elliptical geometry. 
Table 1

Means and standard errors of abiotic land surface properties of the seven landform units in the Mojave Desert.

\begin{tabular}{|c|c|c|c|c|c|c|c|c|c|c|c|c|c|c|c|}
\hline \multirow[b]{4}{*}{ Variable } & & \multicolumn{4}{|c|}{ Young geomorphic surface } & \multicolumn{6}{|c|}{ Intermediate-aged geomorphic surface } & \multicolumn{4}{|c|}{ Old geomorphic surface } \\
\hline & & \multicolumn{14}{|c|}{ Landform unit type } \\
\hline & & \multicolumn{2}{|l|}{$\mathrm{BR}^{\mathrm{a}}$} & \multicolumn{2}{|l|}{$\mathrm{SW}^{\mathrm{b}}$} & \multicolumn{2}{|l|}{$\mathrm{FB}^{\mathrm{C}}$} & \multicolumn{2}{|l|}{$\mathrm{FS}^{\mathrm{d}}$} & \multicolumn{2}{|l|}{$\mathrm{BT}^{\mathrm{e}}$} & \multicolumn{2}{|l|}{$\mathrm{DP}^{\mathrm{f}}$} & \multicolumn{2}{|l|}{$\mathrm{SZ}^{\mathrm{g}}$} \\
\hline & & Mean & SE & Mean & SE & Mean & SE & Mean & SE & Mean & SE & Mean & SE & Mean & SE \\
\hline \multirow[t]{5}{*}{ Clast length } & Mean (mm) & 28.6 & 1.3 & 13.2 & 0.7 & 25.0 & 1.8 & 15.4 & 1.0 & 16.0 & 0.4 & 23.6 & 1.1 & 14.7 & 0.5 \\
\hline & Median (mm) & 21.7 & 1.7 & 11.3 & 0.6 & 18.8 & 2.0 & 13.0 & 0.9 & 13.1 & 0.5 & 19.7 & 0.8 & 12.2 & 0.5 \\
\hline & Sorting $(\phi)$ & 1.11 & 0.08 & 0.77 & 0.03 & 1.13 & 0.10 & 0.84 & 0.07 & 0.87 & 0.07 & 1.03 & 0.09 & 0.80 & 0.04 \\
\hline & Skew. ${ }^{1}$ & -0.14 & 0.09 & -0.25 & 0.10 & -0.16 & 0.10 & -0.17 & 0.13 & -0.30 & 0.11 & 0.08 & 0.15 & -0.20 & 0.09 \\
\hline & Kurt. $^{\mathrm{m}}$ & -0.20 & 0.17 & 0.39 & 0.28 & -0.48 & 0.13 & 0.20 & 0.12 & 0.31 & 0.46 & -0.14 & 0.22 & -0.01 & 0.09 \\
\hline \multirow[t]{5}{*}{ Clast width } & Mean (mm) & 19.4 & 0.8 & 8.9 & 0.4 & 16.5 & 1.2 & 10.0 & 0.6 & 9.8 & 0.8 & 15.5 & 0.7 & 9.3 & 0.7 \\
\hline & Median (mm) & 14.3 & 1.0 & 7.5 & 0.4 & 12.5 & 1.3 & 8.5 & 0.6 & 8.4 & 0.8 & 12.9 & 0.6 & 7.9 & 0.6 \\
\hline & Sorting $(\phi)$ & 1.10 & 0.08 & 0.78 & 0.02 & 1.10 & 0.09 & 0.80 & 0.06 & 0.84 & 0.07 & 0.99 & 0.09 & 0.78 & 0.04 \\
\hline & Skew. & -0.24 & 0.11 & -0.29 & 0.07 & -0.18 & 0.09 & -0.17 & 0.11 & -0.27 & 0.09 & 0.00 & 0.18 & -0.18 & 0.08 \\
\hline & Kurt. $^{\mathrm{m}}$ & -0.19 & 0.15 & 0.13 & 0.33 & -0.34 & 0.16 & 0.07 & 0.20 & -0.04 & 0.15 & 0.10 & 0.34 & -0.04 & 0.06 \\
\hline \multirow[t]{4}{*}{ Physical Cover (\%) } & Bare Soil & 1.7 & 0.6 & 2.2 & 0.7 & 2.7 & 0.6 & 4.0 & 0.5 & 8.7 & 1.4 & 4.1 & 0.5 & 7.5 & 1.3 \\
\hline & Gravel & 41.1 & 2.7 & 75.9 & 4.3 & 53.6 & 4.4 & 74.8 & 3.5 & 39.9 & 4.8 & 90.8 & 0.9 & 37.9 & 3.2 \\
\hline & Cobbles & 14.8 & 3.5 & 0.5 & 0.3 & 8.7 & 2.3 & 0.3 & 0.3 & 1.1 & 0.7 & 3.4 & 0.8 & 0.1 & 0.1 \\
\hline & Total & 57.5 & & 78.6 & & 65.0 & & 79.2 & & 49.7 & & 98.3 & & 45.5 & \\
\hline Clast den. ${ }^{\mathrm{h}}$ & $\mathrm{N}$ & 58.6 & 6.6 & 127.5 & 16.3 & 71.1 & 8.5 & 111.6 & 13.8 & 94.8 & 15.4 & 75.0 & 4.5 & 83.5 & 11.0 \\
\hline $\mathrm{RI}^{\mathrm{i}}$ & & 2.5 & 0.1 & 0.9 & 0.1 & 1.7 & 0.1 & 0.8 & 0.1 & 1.4 & 0.1 & 0.5 & 0.0 & 0.8 & 0.1 \\
\hline Areal ext. ${ }^{\mathrm{j}}$ & $\mathrm{m}^{2}$ & 90 & 12 & 104 & 12 & 121 & 19 & 161 & 22 & 84 & 20 & 2859 & 1383 & 799 & 281 \\
\hline Embedd. $^{\mathrm{k}}$ & $\mathrm{N}$ & 7.7 & 0.6 & 2.5 & 0.4 & 8.0 & 0.6 & 2.7 & 0.5 & 2.0 & 0.3 & 8.5 & 1.0 & 3.7 & 0.6 \\
\hline
\end{tabular}

a $\mathrm{BR}=$ bar.

b $\mathrm{SW}=$ swale

c $\mathrm{FB}=$ flattened bar

${ }^{\mathrm{d}} \mathrm{FS}=$ flattened swale

e $\mathrm{BT}=$ bioturbated.

${ }^{\mathrm{f}} \mathrm{DP}=$ desert pavement.

g $\mathrm{SZ}=$ shrub zone.

h Clast den. = clast density.

i $\mathrm{RI}$. = roughness index.

j Areal ext. = areal extent of the landform units.

$\mathrm{k}$ Embedd. = clast embeddedness.

1 Skew. = skewness.

$\mathrm{m}$ Kurt. $=$ kurtosis.

Physical land surface properties, such as density, type, and distributional parameters of surface clasts were characterized along the longest axis of a studied landform unit at three systematic locations. The longest axis was divided into three segments. A 1-m tape was placed at the center of each segment, one pace away from the longest axis best attain undisturbed ground. Length and width of each clast touching the tape was measured (Folk, 1980). Clast sorting was calculated using Folk's logarithmic transformation criteria and transformed to the $\phi$-scale (Folk, 1980). High values represent a low degree of sorting, i.e., a larger spread of clast sizes. Low values of sorting are obtained when most of the clasts have the same dimensions. Phi scale skewness and kurtosis were calculated to interpret the clast frequency distribution (Folk, 1980). Skewness can be used to evaluate the symmetry of sediment or surface clast distribution. Negative skewness of the sediment distribution indicates an asymmetric tail in the coarse fractions, whereas positive skewness indicates an asymmetric tail in the fine fractions (Folk, 1980). Kurtosis describes the ratio between the spread of sediment sizes in the central and the tail portion of the distribution. A leptokurtic sediment distribution has an acute narrow central peak of sediment sizes with a broad range of sizes at the coarse and fine tail ends. In contrast, a platykurtic sediment size distribution is one in which there is a broad and flat central distribution with a narrower range of sediment sizes in the tails (Folk, 1980). The soil embeddedness (= tight lodging of surface rocks into the soil) of the clasts touching the tape was recorded as presence or absence. Surface roughness describes the microtopography of a site and was recorded by placing a roller chain one pace away from the 1-m tape and calculated using the methodology of Saleh (1993). Percent ground cover of physical components was assessed in combination with the biological characterization as follows.

Biological characterization included determining abundance and diversity of biological soil crust community types and vascular plant functional groups using cover and frequency quadrats. Biological soil crust community identification was made according to Pietrasiak et al. (2011a, 2013) and included: incipient algal/fungal crust, light algal crust ( = unblackened algal crust), dark algal crust (= blackened algal crust), cyanolichen crust, green algal lichen crust and moss crust. Plant functional groups included: annual grasses, annual forbs, perennial grasses, perennial forbs, woody shrubs and cacti. Ground cover of biological soil crust community types, plant functional groups, and physical components was assessed using point intercept measurements of a $0.25-\mathrm{m}^{2}$ quadrat with 25 string intersections. The quadrat was systematically placed along the longest axis of the studied landform unit. A minimum of 100 cover point intercepts was required for each unit. Frequency of biotic land surface components was recorded using a $1-\mathrm{m}^{2}$ quadrat placed along the longest axis of the landform unit. Because units varied in size from $10 \mathrm{~m}^{2}$ to $100 \mathrm{~m}^{2}$ (Table 1 ), the number of cover and frequency quadrat placements along the longest axis of the unit was increased systematically with increases in unit size; i.e., in a $10 \mathrm{~m}^{2}$ studied landform unit, quadrats were placed every meter whereas in a $100 \mathrm{~m}^{2}$ studied landform unit, quadrats were placed every $10 \mathrm{~m}$. Shannon diversity $\left(\mathrm{e}^{\mathrm{H}}\right)$ was computed using cover values (Gurevitch et al., 2006). Richness, as the number of plant functional groups and crust community types, was calculated using presence and absence data derived from frequency data.

\subsection{Statistical analysis}

Descriptive statistics for land surface properties and the following analyses were performed in SAS 9.1. Statistical differences in plant functional group and crust community diversity and richness between landform units were detected with ANOVA followed by a Tukey's test, using the PROC GLM statement in SAS. Several multivariate statistical analyses 
were performed to distinguish and classify landform units and to investigate the factors driving the biotic communities. MANOVA is a statistical method that investigates the mean difference and statistical significance between treatments or group memberships based on multiple response variables (Tabachnik and Fidell, 2007). In this case, we used MANOVA to understand how abiotic and biotic variables might help us describe and delineate landform units as well as determine which variables most strongly drive these distinctions. Significance of the seven landform units as related to a combination of response variables (morphometric, biological, and physical land surface properties) was tested with the PROC GLM statement and a MANOVA model in SAS. A significant MANOVA model allows for further investigation of the data via discriminant analysis (DA). DA uses the response variables as predictor variables to classify the treatments or groups and visualize the difference in ordinal space (Tabachnik and Fidell, 2007). This analysis discerns canonical correlations of morphometric, physical, and biological variables within their group memberships "landform unit". Therefore, with this analysis, we can visually see how various combinations of abiotic and biotic variables influence the dissimilarity or similarity of our landform units. This analysis approach (MANOVA and DA) has been applied to a similar system in the Mojave Desert to understand the roles of land surface properties on the interactions between soils and geomorphology in arid mountains (Hirmas et al., 2011). For both analyses, MANOVA and DA response variables were: (1) morphometric - landform unit area and slope shape; (2) physical - mean and median clast dimension; mean clast sorting, clast skewness and kurtosis; mean clast density; mean microtopographic roughness index and embeddedness; and (3) biological - ground cover of plant functional groups and biological soil crust communities. Morphometric and physical variables were combined to represent abiotic factors. Dummy variables were created for slope shape for both the cross and profile shape. Only four of the five possible slope variables were considered in the analyses, since recognizing all four variables results in the identification of the fifth. Tukey tests were performed on landform unit class means of the first two canonical variables consisting of a linear combination of the response variables in SAS. MANOVAs and DAs were run for: abiotic variables only (morphometric and physical); crust community type only; plant functional type only; biotic variables only (crust community types and plant functional groups); and combined abiotic and biotic variables. The importance of response variables was interpreted by the value of their computed canonical coefficients. Accordingly, coefficients that are larger discriminate landform units greater and thus, represent stronger drivers of a pattern observed. Either a positive or negative coefficient sign indicates the direction of the association between a response variable and the linear combination. For each DA, scatterplots were created to show the ordination pattern of the seven landform units.

A third multivariate statistical technique was performed to test which of the abiotic factors significantly drive the composition of crust and plant communities. Canonical correspondence analysis (CCA) is an analysis in which multiple dependent response variables can be related to multiple independent explanatory variables (Lepš and Šmilauer, 2003). With this analysis, we could discern relationships between environmental factors and biotic communities as has been previously done for both microbial and plant communities (FernandezGimenez and Allen-Diaz, 2001; El-Bana et al., 2002; Drenovsky et al., 2010; Pietrasiak et al., 2011a,b). Thus, associations of physical and morphometric variables as explanatory variables with the assemblage of crust communities and plant functional types as response variables were investigated in CANOCO v4.5. A cover data matrix of crust communities and plant functional groups was used for the CCA. Perennial grasses rarely occurred in frequency quadrats and therefore were omitted as a response variable in the CCA. Explanatory variables were: (1) morphometric - landform unit area and slope shape; and (2) physical - mean clast dimension; mean clast sorting, skewness, kurtosis, and density; mean microtopographic roughness index and embeddedness. Median clast dimension was not included in the analysis due to high covariance with mean clast dimension.

\section{Results}

\subsection{Landform structure and composition: abiotic properties}

Overall, the fan skirt was dominated by physical components as assessed by percent cover of physical and biological components. On average $67 \%$ of the fan skirt land surface was covered by physical components with a clast density of $89 \%$. Specifically, the cover of gravel and cobble combined was greater than $>38 \%$ for all landform units (Table 1 ). With increasing geomorphic age, the geomorphic surfaces showed a trend towards improved clast sorting and a homogenous clast distribution ( $=$ a slight decrease in sorting values, Table 1$)$. No bimodal clast distribution was detected for any units. The bars, flattened bars, swales, flattened swales, bioturbation units, and shrub zones had slight excess in coarse fragments (negative sign of skewness), whereas desert pavement had slight excess in fine material (positive sign of skewness, Table 1). With increasing age from bar, flattened bar, and desert pavement there was a decrease in microtopography and clast dimensions noticeable (Table 1). Swales and flattened swales increased in clast dimension and decreased slightly in microtopography with increasing geomorphic age. All units are flat-peaked in kurtosis values (kurtosis $<1.00$ ).

\subsubsection{Young geomorphic surface - bars and swales}

The geomorphically young swale units were dominated by physical components as assessed by percent cover, in particular by gravel-sized clasts (Table 1). The bar units had more cobble-sized clasts and almost $50 \%$ fewer gravel-sized clasts as ground cover compared to swales (Table 1). Also, bar clasts were twice as large as swale clasts (mean and median, Table 2). Microtopography, as indicated by the roughness index, was more than $50 \%$ greater in bar units compared to swales. Moreover, bars were less sorted than swales (length and width sorting $\sigma_{\mathrm{I}}>1 \phi$, Table 2) and classified as poorly sorted. Swales were classified as moderately well sorted $\left(\sigma_{\mathrm{I}}>0.75-1 \phi\right.$, Folk, 1980). Bar units had the highest microtopography amongst all units (highest RI, Table 2), and more rocks were embedded into the surface in bar units than in swales (Table 2).

\subsubsection{Intermediate-aged geomorphic surface - flattened bars, flattened swales and bioturbated units}

The intermediate-aged flattened swales had similar values of physical component coverage compared to the young swales (bare soil, gravel and cobble-sized clasts, Table 1). Intermediate-aged bar units had 50\% less cobble coverage and 50\% greater gravel coverage. In addition, mean and median clast dimensions decreased slightly in flattened bar units (Table 2). There was a slight increase in mean and median dimensions for flattened swales. Flattened bar units were still characterized by a rougher topography, poorer sorting $\left(\sigma_{\mathrm{I}}>1 \phi\right)$, and higher degree of embeddedness when compared to the flattened swales. However, roughness decreased from 2.5 to 1.7 from young to intermediate geomorphic age (Table 2 ).

The intermediate-aged bioturbation units had the lowest cover of physical components (less than half of land surface cover) with the lowest gravel-sized clast cover (Table 1). These units were characterized by greater proportion of bare soil compared to the other units (Table 1). Also, bioturbated units were moderately sorted and had the fewest embedded clasts compared to all other units. Microtopography was moderate, with an index value of 1.4

\subsubsection{Old geomorphic surface - desert pavements and shrub zone}

Desert pavement units were almost completely covered by physical components (98\%, Table 1), with $90 \%$ of the cover being gravel. Desert pavements had the lowest microtopography index value of all the 
Table 2

Means and standard errors of biotic land surface properties of the seven landform units in the Mojave Desert.

\begin{tabular}{|c|c|c|c|c|c|c|c|c|c|c|c|c|c|c|c|c|}
\hline \multirow[b]{4}{*}{ Variable } & & & \multicolumn{4}{|c|}{ Young geomorphic surface } & \multicolumn{6}{|c|}{ Intermediate-aged geomorphic surface } & \multicolumn{4}{|c|}{ Old geomorphic surface } \\
\hline & & & \multicolumn{14}{|c|}{ Landform unit type } \\
\hline & & & \multicolumn{2}{|l|}{$\mathrm{BR}^{\mathrm{a}}$} & \multicolumn{2}{|l|}{$\mathrm{SW}^{\mathrm{b}}$} & \multicolumn{2}{|l|}{$\mathrm{FB}^{\mathrm{c}}$} & \multicolumn{2}{|l|}{$\mathrm{FS}^{\mathrm{d}}$} & \multicolumn{2}{|l|}{$\mathrm{BT}^{\mathrm{e}}$} & \multicolumn{2}{|l|}{$D P^{f}$} & \multicolumn{2}{|l|}{$\mathrm{SZ}^{\mathrm{g}}$} \\
\hline & & & Mean & SE & Mean & SE & Mean & SE & Mean & SE & Mean & SE & Mean & SE & Mean & SE \\
\hline \multirow{15}{*}{$\begin{array}{l}\text { Cover } \\
(\%)\end{array}$} & Biological & $\mathrm{IC}^{\mathrm{h}}$ & 3.3 & 1.0 & 3.9 & 1.2 & 4.5 & 1.3 & 1.4 & 0.5 & 6.9 & 1.8 & 0.1 & 0.1 & 9.0 & 1.4 \\
\hline & Soil & $\mathrm{LAC}^{\mathrm{i}}$ & 2.7 & 0.6 & 1.4 & 0.5 & 2.1 & 0.6 & 0.6 & 0.2 & 0.8 & 0.4 & 0.0 & 0.0 & 3.3 & 0.5 \\
\hline & Crust & $\mathrm{DAC}^{\mathrm{j}}$ & 0.2 & 0.2 & 0.1 & 0.1 & 0.0 & 0.0 & 0.0 & 0.0 & 0.0 & 0.0 & 0.0 & 0.0 & 0.0 & 0.0 \\
\hline & & $\mathrm{CLC}^{\mathrm{k}}$ & 5.4 & 1.2 & 1.5 & 0.7 & 1.0 & 0.4 & 1.0 & 0.3 & 0.1 & 0.1 & 0.0 & 0.0 & 0.7 & 0.3 \\
\hline & & $\mathrm{GLC}^{\mathrm{l}}$ & 1.0 & 0.6 & 0.1 & 0.1 & 0.4 & 0.2 & 0.2 & 0.1 & 0.2 & 0.2 & 0.0 & 0.0 & 0.0 & 0.0 \\
\hline & & $\mathrm{MC}^{\mathrm{m}}$ & 2.3 & 1.0 & 0.1 & 0.1 & 0.2 & 0.1 & 0.0 & 0.0 & 0.0 & 0.0 & 0.0 & 0.0 & 0.0 & 0.0 \\
\hline & & Total & 14.9 & & 7.0 & & 8.1 & & 3.2 & & 8.0 & & 0.1 & & 13.1 & \\
\hline & Vascular & $\mathrm{AG}^{\mathrm{n}}$ & 4.9 & 0.8 & 3.4 & 1.7 & 6.3 & 0.6 & 3.0 & 0.8 & 12.6 & 3.0 & 0.1 & 0.1 & 4.3 & 1.2 \\
\hline & Plants & $\mathrm{AF}^{\mathrm{O}}$ & 1.9 & 0.8 & 1.2 & 0.4 & 2.7 & 0.9 & 1.5 & 0.9 & 1.0 & 0.4 & 0.1 & 0.1 & 2.8 & 1.0 \\
\hline & & $\mathrm{PEG}^{\mathrm{P}}$ & 0.0 & 0.0 & 0.0 & 0.0 & 0.0 & 0.0 & 0.0 & 0.0 & 0.0 & 0.0 & 0.0 & 0.0 & 0.0 & 0.0 \\
\hline & & $\mathrm{PEF}^{\mathrm{q}}$ & 0.0 & 0.0 & 0.0 & 0.0 & 0.0 & 0.0 & 0.0 & 0.0 & 0.0 & 0.0 & 0.0 & 0.0 & 0.2 & 0.2 \\
\hline & & $W^{r}$ & 15.5 & 3.8 & 5.4 & 1.7 & 11.0 & 2.0 & 8.1 & 3.0 & 20.6 & 2.9 & 0.8 & 0.4 & 24.2 & 4.2 \\
\hline & & $\mathrm{C}^{\mathrm{s}}$ & 0.2 & 0.2 & 0.2 & 0.2 & 1.3 & 1.3 & 0.6 & 0.5 & 0.1 & 0.1 & 0.0 & 0.0 & 0.6 & 0.4 \\
\hline & & Total & 22.6 & & 10.2 & & 21.2 & & 13.3 & & 34.3 & & 1.0 & & 32.1 & \\
\hline & Litter & & 5.0 & 0.9 & 4.2 & 1.1 & 5.6 & 1.4 & 4.4 & 0.9 & 8.0 & 1.4 & 0.6 & 0.1 & 9.2 & 1.1 \\
\hline \multirow{14}{*}{$\begin{array}{l}\text { Frequency } \\
(\%)\end{array}$} & Biological & $\mathrm{IC}^{\mathrm{h}}$ & 100.0 & 0.0 & 89.3 & 8.9 & 93.1 & 3.5 & 84.4 & 7.3 & 95.0 & 3.3 & 18.5 & 4.0 & 100.0 & 0.0 \\
\hline & Soil & $\mathrm{LAC}^{\mathrm{i}}$ & 90.4 & 5.7 & 69.0 & 12.6 & 79.4 & 10.5 & 64.4 & 12.8 & 67.2 & 7.9 & 8.5 & 3.3 & 92.0 & 4.1 \\
\hline & Crust & $\mathrm{DAC}^{\mathrm{j}}$ & 6.7 & 6.7 & 1.9 & 1.9 & 1.9 & 1.9 & 0.0 & 0.0 & 0.0 & 0.0 & 0.0 & 0.0 & 1.9 & 1.9 \\
\hline & & $\mathrm{CLC}^{\mathrm{k}}$ & 91.6 & 3.5 & 59.8 & 13.3 & 63.0 & 13.5 & 62.7 & 11.9 & 7.2 & 3.6 & 0.0 & 0.0 & 18.3 & 8.4 \\
\hline & & $\mathrm{GLC}^{1}$ & 77.9 & 7.7 & 16.4 & 7.9 & 48.5 & 15.0 & 23.7 & 10.4 & 2.2 & 2.2 & 0.0 & 0.0 & 3.9 & 2.6 \\
\hline & & $\mathrm{MC}^{\mathrm{m}}$ & 55.2 & 13.8 & 13.4 & 6.4 & 16.3 & 9.3 & 6.4 & 3.5 & 0.0 & 0.0 & 0.0 & 0.0 & 12.1 & 4.8 \\
\hline & & Total & 100.0 & & 89.3 & & 93.1 & & 84.4 & & 95.0 & & 18.5 & & 100.0 & \\
\hline & Vascular & $\mathrm{AG}^{\mathrm{n}}$ & 96.2 & 2.6 & 81.9 & 7.0 & 91.7 & 4.4 & 84.8 & 8.7 & 100.0 & 0.0 & 23.7 & 6.5 & 95.9 & 2.7 \\
\hline & Plants & $\mathrm{AF}^{\circ}$ & 91.1 & 6.8 & 68.9 & 14.2 & 87.8 & 8.1 & 93.3 & 4.7 & 81.1 & 9.5 & 25.8 & 6.5 & 88.1 & 5.1 \\
\hline & & $\mathrm{PEG}^{\mathrm{p}}$ & 2.2 & 2.2 & 1.6 & 1.6 & 0.0 & 0.0 & 2.2 & 2.2 & 0.0 & 0.0 & 0.0 & 0.0 & 0.0 & 0.0 \\
\hline & & $\mathrm{PEF}^{\mathrm{q}}$ & 0.0 & 0.0 & 0.0 & 0.0 & 0.0 & 0.0 & 0.0 & 0.0 & 0.0 & 0.0 & 0.0 & 0.0 & 5.8 & 3.1 \\
\hline & & $W S^{r}$ & 87.5 & 4.4 & 61.6 & 6.2 & 71.3 & 3.7 & 62.2 & 7.5 & 87.2 & 5.8 & 14.1 & 1.6 & 88.3 & 4.8 \\
\hline & & $C^{s}$ & 9.7 & 4.6 & 3.7 & 2.4 & 2.8 & 2.8 & 3.0 & 2.0 & 2.8 & 2.8 & 0.0 & 0.0 & 6.7 & 3.2 \\
\hline & & Total & 96.2 & & 81.9 & & 91.7 & & 93.3 & & 100.0 & & 25.8 & & 95.9 & \\
\hline
\end{tabular}

a $\mathrm{BR}=$ bar.

b $\mathrm{SW}=$ swale.

c $\mathrm{FB}=$ flattened bar.

d $\mathrm{FS}=$ flattened swale

e $\mathrm{BT}=$ bioturbated.

f $\mathrm{DP}=$ desert pavement.

g $\mathrm{SZ}=$ shrub zone.

h IC = incipient algal/fungal crust.

i $\mathrm{LAC}=$ light algal crust.

j $\mathrm{DAC}=$ dark algal crust.

k $\mathrm{CLC}=$ cyanolichen crust.

${ }^{1} \mathrm{GLC}=$ green algal lichen crust

$\mathrm{m} M \mathrm{MC}=$ moss crust.

${ }^{n} \mathrm{AG}=$ annual grasses

- $\mathrm{AF}=$ annual forbs.

p $P E G=$ perennial grasses.

q $\mathrm{PEF}=$ perennial forbs.

${ }^{r}$ WS $=$ woody shrubs.

s $\mathrm{C}=$ cacti.

units as well as the most clasts embedded into the soil surface. Sorting improved slightly (a slight decrease in sorting value) compared to the young bars and swales and the intermediate flattened bars and swales (Table 1). Clasts were mostly gravel and were less coarse than the clasts in bar and flattened bar units (Table 1 ).

Shrub zone units were very similar to bioturbation units with a low cover of physical components, a relatively high cover of bare soil, moderate sorting, and low clast embeddedness. Roughness decreased by almost half in shrub zone units compared to the bioturbated units (Table 1).

\subsection{Landform structure and composition: biotic properties}

Generally, three trends in biotic land surface properties could be observed with increasing geomorphic age (Table 2): (1) cover and frequency of biological soil crusts and plants decreased from young bars and swales, to intermediate flattened bars and swales, to old desert pavement units; (2) biological soil crust cover increased from intermediate bioturbation units to old shrub zone units; and (3) crust and plant frequency and plant cover were similar in intermediate bioturbation units and old shrub zone units. The greatest contrasts of plant and biological soil crust coverage were found on the two oldest geomorphic surfaces - desert pavements, with almost no biotic cover, and shrub zones, with some of the highest plant and biological soil crust coverage.

\subsubsection{Plants}

Vascular plants covered on average of $20 \%$ of the total fan skirt landform. Plant cover was highest in bioturbation and shrub zone units (Table 2). Plant cover for the other units ranks in decreasing order as follows: bars, flattened bars, swales, flattened swales, and desert pavements (Table 2). Percent plant frequency ranged from 26\% on desert pavements to $100 \%$ in bioturbation units. Woody shrubs, annual forbs, and grasses were the most common functional groups for all units. Perennial grasses, forbs, and cacti were rare, overall, but had the highest 
frequency on bars and shrub zones (Table 2). Perennial grasses were only recorded in the young bars, swales, and flattened swales. Perennial forbs were the most rare plant functional group and were only found in shrub zones with a low frequency (Table 2).

\subsubsection{Biological soil crusts}

In general, biological soil crust cover was relatively low over the entire fan skirt area (total mean $=8 \%$ ). However, it reached up to a maximum of $26 \%$ cover within some of the land surface units. The highest total crust cover was found in the bars and shrub zones with almost double the cover of the grand mean (Table 2). In bars all six crust types were recorded, whereas in shrub zones, only incipient and light algal crusts as well as a small percent of cyanolichen crusts were detected. Swales, flattened bars, bioturbated and shrub zone units had intermediate crust cover (Table 2). Flattened swales had a very low crust cover value (Table 2). Desert pavements were devoid of crust cover (Table 2). Lichen, moss and dark algal crusts were the most patchily distributed, with their greatest cover and frequency in young bar units. The most common crust types for all units were incipient and light algal crusts. Bars were the only units where a lichen crust type (CLC, Table 2) covered more ground than an algal crust type. Cyanolichen crusts were the most common non-algae dominated crust type (Table 2).

\subsection{Land surface units as discrete statistical units based on surface properties}

All five MANOVAs comparing the abiotic $\left(F_{132,165}=6.51\right)$, biotic $\left(F_{30,210}=3.62\right)$, combined abiotic and biotic $\left(F_{198,103}=6.68\right)$, crust communities $\left(F_{36,227}=3.85\right)$ and plant functional groups $\left(F_{30,210}=\right.$ 3.06) among the seven landforms were highly significant $(p<0.001)$ using the Wilks' Lambda significance test. Thus, in all five cases the linear combination of response variables was significantly different for at least one of the seven landform unit types in comparison to the others. Additionally, all discriminant analysis (DA) models (abiotic, biotic, combined abiotic and biotic, crust communities and plant functional groups) explained more than $75 \%$ of the variability. The strongest classification model was obtained by using a combined abiotic and biotic land surface property data matrix. In contrast, the weakest classification model included only the plant functional groups and crust communities. Thus, after a brief description of the two abiotic and biotic only models, discussion of the results will focus on the combined model.

In the abiotic only DA, almost all seven landform units appeared as statistically distinct and widely separated units due to differences in abiotic land surface properties within the landscape (Fig. 2a). There was no significant difference between swales and flattened swale units and thus these units were not spatially separated in this DA. In contrast, the DA using a biotic land surface classification did not reveal such discrete units as compared to the abiotic classification, with substantial overlap between landform units (Fig. 2b). Distinct separation of landform units in the biotic DA plot was only revealed for bars, shrub zones, and desert pavements. The other four units showed a gradual overlap and no distinct spatial separation. Also, the canonical coefficients using biotic variables were weaker than in the abiotic analysis; i.e., never exceeded 1.

Compared to the abiotic or biotic only DAs, the combined abiotic and biotic discriminant plot showed the widest separation of the landform units and was the best-fit model of all DAs performed (Fig. 2c). Moreover, the canonical coefficients associated with the DA based on abiotic and biotic land surface properties combined had the highest values of all discriminant analyses (Table 3). However, even with the inclusion of the biotic variables, abiotic variables were still the strongest drivers of the analysis (i.e., highest canonical coefficients).

About $76 \%$ of the variability was explained with the first two discriminant axes. Axis one accounted for $45 \%$ of the variation and separated the units from left to right due to an increase of clast dimensions, microtopography, higher diversity of crust types and a shift of annuals (Table 3). In addition, the axis described a transition from concave to
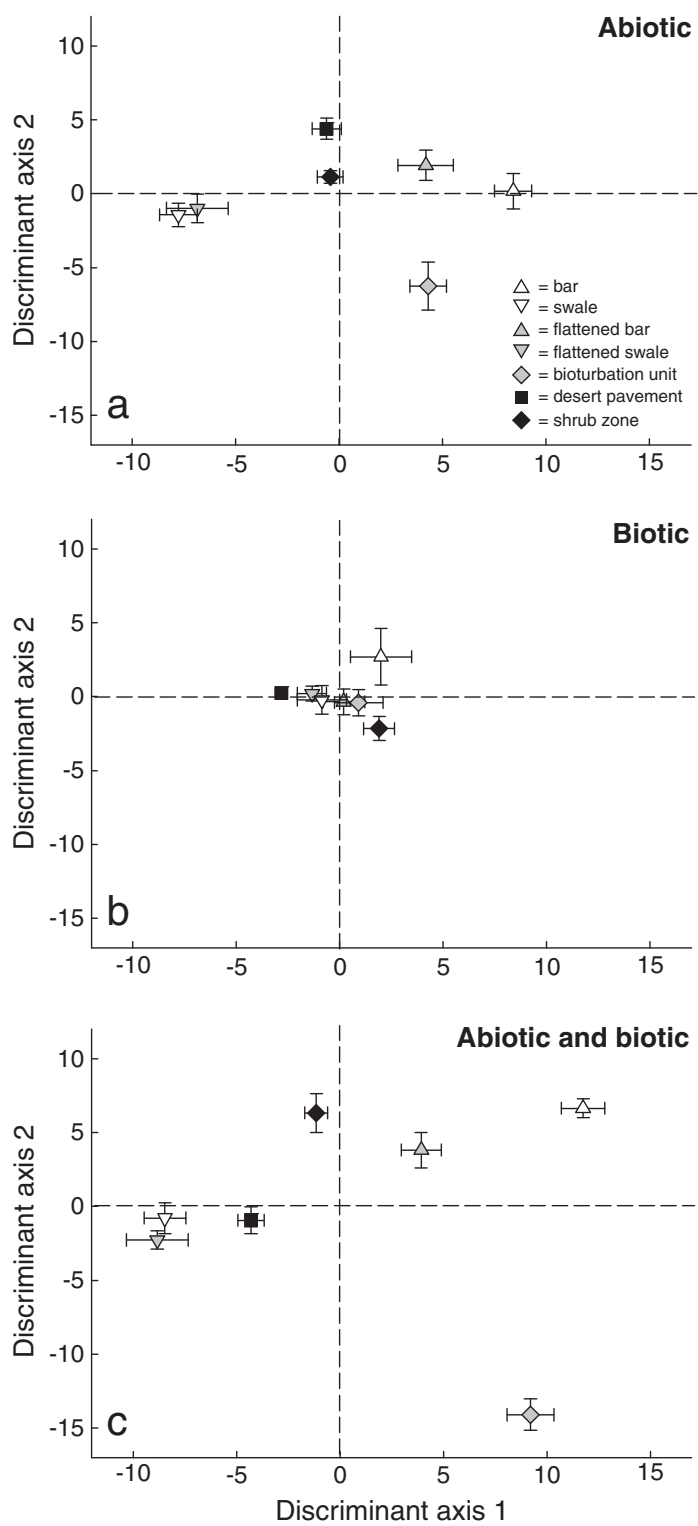

Fig. 2. Discriminant analysis plots for abiotic and biotic land surface properties showing the first two axis. Biplots represent the (a) abiotic only, (b) biotic only, and (c) abiotic and biotic combined discriminant analysis. Error bars on centroids represent one standard deviation. White symbols represent units found on young, grey represent units on intermediate and black represents units on old geomorphic surfaces.

linear to convex landform morphometry (Table 3). Consequently, bars and flattened bars, and to some degree bioturbation units plotted on the right (Fig. 2c). They were classified as convex units with large clasts and high microtopography but also had higher coverage of annual grasses and greater diversity of crust communities including incipient crust, moss crusts and green lichen crusts (Table 3). In contrast, swales and flattened swales that plotted on the left were classified as concave, small clast covered, less roughened units with higher annual forb coverage and lower biological soil crust diversity and coverage (Fig. 2c, Table 3). Desert pavements also plotted on the left side, sharing more similarities in abiotic and biotic land surface characteristics with swales and flattened swales, than with bars and flattened bars (Fig. 2c).

Axis two explained $31 \%$ of the variation and was associated with distinguishing shrub zones and bars from bioturbation units (Fig. 2c). This axis depicts a gradient that combined improved clast sorting and density, decreasing relief, increasing algal crust type diversity and woody shrub coverage, as well as decreasing cover of annual grasses (Table 3). Therefore, the bioturbation units positioned lowest in the 
Table 3

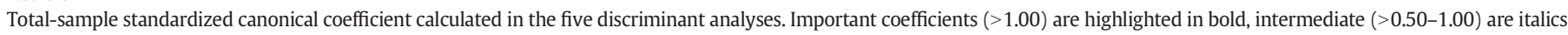

\begin{tabular}{|c|c|c|c|c|c|c|c|c|c|c|c|}
\hline \multirow[t]{2}{*}{ Predictor variables } & & \multicolumn{2}{|l|}{ Abiotic } & \multicolumn{2}{|c|}{ Biotic } & \multicolumn{2}{|c|}{ Abiotic and biotic } & \multicolumn{2}{|l|}{$\mathrm{CCT}^{\mathrm{a}}$} & \multicolumn{2}{|l|}{$\mathrm{PFG}^{\mathrm{b}}$} \\
\hline & & $\mathrm{DA} 1^{\mathrm{c}}$ & $\mathrm{DA} 2^{\mathrm{d}}$ & $\mathrm{DA} 1^{\mathrm{c}}$ & $\mathrm{DA} 2^{\mathrm{d}}$ & $\mathrm{DA} 1^{\mathrm{c}}$ & $\mathrm{DA} 2^{\mathrm{d}}$ & $\mathrm{DA} 1^{\mathrm{c}}$ & $\mathrm{DA} 2^{\mathrm{d}}$ & $\mathrm{DA} 1^{\mathrm{c}}$ & $\mathrm{DA} 2^{\mathrm{d}}$ \\
\hline \multirow[t]{5}{*}{ Clast length } & Mean & 5.56 & -2.01 & - & - & 5.45 & 2.68 & - & - & - & - \\
\hline & Med. ${ }^{\mathrm{k}}$ & -5.50 & 3.56 & - & - & -6.99 & -1.71 & - & - & - & - \\
\hline & Sort. ${ }^{1}$ & -1.31 & 2.26 & - & - & 0.43 & -6.04 & - & - & - & - \\
\hline & Skew. ${ }^{\mathrm{m}}$ & 0.27 & -3.52 & - & - & -0.55 & 0.56 & - & - & - & - \\
\hline & Kurt. $^{\mathrm{n}}$ & 0.08 & 0.37 & - & - & 0.27 & -0.37 & - & - & - & - \\
\hline \multirow[t]{5}{*}{ Clast width } & Mean & -4.50 & -0.74 & - & - & -4.70 & -1.85 & - & - & - & - \\
\hline & Med. ${ }^{k}$ & 5.36 & 0.50 & - & - & 7.13 & 2.05 & - & - & - & - \\
\hline & Sort. ${ }^{1}$ & 1.16 & 0.33 & - & - & -0.80 & 5.85 & - & - & - & - \\
\hline & Skew. ${ }^{\mathrm{m}}$ & -0.19 & -0.27 & - & - & 0.80 & -0.23 & - & - & - & - \\
\hline & Kurt. $^{\mathrm{n}}$ & -0.18 & 0.17 & - & - & -0.16 & 0.54 & - & - & - & - \\
\hline Clast d. $^{\mathrm{e}}$ & & -0.03 & 0.03 & - & - & 0.26 & 1.82 & - & - & - & - \\
\hline $\mathrm{RI}^{\mathrm{f}}$ & & 2.02 & -0.56 & - & - & 4.07 & 0.44 & - & - & - & - \\
\hline Embed. ${ }^{g}$ & & 0.82 & 0.94 & - & - & 0.49 & 0.86 & - & - & - & - \\
\hline \multirow[t]{4}{*}{ X sect. ${ }^{\mathrm{h}}$} & Lin. $^{\circ}$ & 2.01 & 1.19 & - & - & 2.28 & 0.04 & - & - & - & - \\
\hline & Conv. ${ }^{\mathrm{p}}$ & 3.03 & -0.09 & - & - & 3.64 & -0.32 & - & - & - & - \\
\hline & Sconv. ${ }^{q}$ & 2.99 & 0.90 & - & - & 3.47 & 0.99 & - & - & - & - \\
\hline & Conc. $^{\mathrm{r}}$ & -0.15 & 0.03 & - & - & 0.04 & 0.21 & - & - & - & - \\
\hline \multirow[t]{4}{*}{ Pro sect. ${ }^{\mathrm{i}}$} & Lin. $^{\circ}$ & -0.14 & -0.04 & - & - & -0.13 & 0.52 & - & - & - & - \\
\hline & Conv. ${ }^{\mathrm{p}}$ & 0.61 & -1.31 & - & - & 1.03 & -2.35 & - & - & - & - \\
\hline & Sconv. ${ }^{q}$ & 0.14 & -0.10 & - & - & -0.03 & 2.27 & - & - & - & - \\
\hline & Conc. $^{\mathrm{r}}$ & 0.84 & -0.87 & - & - & 1.41 & -1.70 & - & - & - & - \\
\hline Unit area & & 0.18 & 0.28 & - & - & 0.02 & 0.13 & - & - & - & - \\
\hline \multirow[t]{12}{*}{ Cov. } & $\mathrm{IC}^{\mathrm{S}}$ & - & - & 0.68 & -0.61 & 0.87 & 1.02 & 0.03 & 0.91 & - & - \\
\hline & LAC $^{t}$ & - & - & 0.46 & -0.30 & 0.02 & 1.04 & 0.20 & 0.85 & - & - \\
\hline & $\mathrm{DAC}^{\mathrm{u}}$ & - & - & 0.09 & -0.45 & 0.33 & 0.64 & -0.05 & 0.33 & - & - \\
\hline & $\mathrm{CLC}^{\mathrm{v}}$ & - & - & 0.41 & 0.79 & 0.02 & -0.08 & 0.92 & -0.33 & - & - \\
\hline & $\mathrm{GLC}^{\mathrm{w}}$ & - & - & 0.23 & 0.91 & 0.51 & 0.31 & 0.54 & -0.42 & - & - \\
\hline & $M C^{\mathrm{x}}$ & - & - & 0.40 & 0.65 & 0.59 & 0.31 & 0.55 & 0.04 & - & - \\
\hline & $A G^{y}$ & - & - & 0.35 & 0.26 & 0.78 & -2.87 & - & - & 0.60 & -1.09 \\
\hline & $\mathrm{AF}^{\mathrm{z}}$ & - & - & 0.21 & 0.66 & -0.69 & 0.14 & - & - & 0.16 & 0.71 \\
\hline & $\mathrm{PEG}^{\mathrm{aa}}$ & - & - & 0.00 & 0.00 & 0.00 & 0.00 & - & - & 0.00 & 0.00 \\
\hline & $\mathrm{PEF}^{\mathrm{ab}}$ & - & - & 0.01 & -0.14 & 0.10 & -0.30 & - & - & 0.02 & 0.33 \\
\hline & $\mathrm{WS}^{\mathrm{ac}}$ & - & - & 0.85 & -0.06 & -0.14 & 1.20 & - & - & 1.07 & 0.58 \\
\hline & $\mathrm{C}^{\mathrm{ad}}$ & - & - & 0.06 & 0.03 & -0.55 & 0.42 & - & - & -0.23 & 0.09 \\
\hline
\end{tabular}

a $\mathrm{CCT}=$ biological soil crust community types.

b $P F G=$ plant functional groups.

c DA1 $=$ discriminant axis 1.

d DA2 = discriminant axis 2 .

e Clast d. = clast density.

${ }^{\mathrm{f}} \mathrm{RI}=$ roughness index.

$\mathrm{g}$ Embedd. = clast embeddedness

h $\mathrm{X}$ sect. $=$ slope cross section.

i Pro sect. = slope profile section.

${ }^{\mathrm{j}}$ Cov. $=$ ground cover of biotic components.

k Med. = median.

${ }^{1}$ Sort. $=$ sorting.

m Skew. = skewness.

${ }^{n}$ Kurt $=$ kurtosis.

o Lin. = linear.

p Conv. $=$ convex.

q Sconv. = slightly convex.

${ }^{\mathrm{r}}$ Conc. $=$ concave

s IC = incipient algal/fungal crust.

${ }^{\mathrm{t}} \mathrm{LAC}=$ light algal crust.

u $\mathrm{DAC}=$ dark algal crust.

v $\mathrm{CLC}=$ cyanolichen crust.

${ }^{\mathrm{w}} \mathrm{GLC}=$ green algal lichen crust.

${ }^{x} \mathrm{MC}=$ moss crust.

y $A G=$ annual grasses

${ }^{z} \mathrm{AF}=$ annual forbs.

aa $\mathrm{PEG}=$ perennial grasses

ab $\mathrm{PEF}=$ perennial forbs

ac $\mathrm{WS}=$ woody shrubs

ad $\mathrm{C}=$ cacti.

plot were classified as convex units with a more heterogeneous clast sorting and more bare soil (Fig. 2c). They also had a higher annual grass coverage compared to the other units. On the other hand, shrub zones, bars, and to a lesser degree flattened bars were more diverse in algal crust types with higher coverage of incipient algal/fungal, light and dark algal crusts and plotted higher (Fig. 2C). These units also had high woody shrub coverage (Table 3 ).
3.4. Plant functional group and crust community richness and Shannon diversity among the landform units

Strong, significant differences in plant functional group and biological soil crust community richness $\left(F_{6,56}=15.32, p<0.001\right)$ and diversity $\left(F_{6,56}=10.39, p<0.001\right)$ were detected among the landform units, with similar patterns in mean separation for both variables. Compared to 
richness, the Shannon diversity index considers both richness and evenness and thus is more informative. Further evaluation will focus on interpretation of Shannon diversity data only. Overall, there was a trend for decreasing diversity observed with geomorphic surface age. However, within the geomorphic surfaces, mesoscale landform units also showed significant differences in functional group and community diversity. Diversity of plant functional groups and biological soil crust community was the lowest in desert pavements and highest in bars (Fig. 3). Intermediate levels of diversity were observed in flattened swales and bioturbation units. Although there was a trend for high diversity in swales, flattened bars and shrub zone units, these values were not significantly different from flattened swales and bioturbation units (Fig. 3).

\subsection{Abiotic factors related to plant functional groups and biological soil crust communities}

Specific abiotic explanatory variables were associated with particular biological soil crust communities and plant functional groups (Fig. 4a). From the suite of environmental variables used in the CCA, only five were significant in the model but explained a total of $77 \%$ of the data variability (Fig. 4a, b). Both environmental gradients (axis 1 , 2 ) cause a gradual spread of the studied landform units (Fig. 4b) based on the distribution of the biological land surface components (response variables), supporting the pattern observed from the biotic DA (data not shown).

The first axis depicts a gradient of geomorphic age with an increase in age from the right to the left site of the plot. This gradient is also linked to clast size and embeddedness. Almost all biological soil crust types plotted on the right side and are found in sites of young to intermediate geomorphic age with coarse-sized embedded clasts (Fig. 4a) such as bars and flattened bars (Fig. 4b). On the other hand, perennial forbs plotted on the left side. Their distribution was driven mostly by an increase in geomorphic age and decrease in clast size and lower clast embeddedness. These plants were strongly associated with shrub zone units (Fig. 4b). All other vascular plants plotted near the origin, and clear relationships to land surface characteristics were difficult to discern.

Axis 2 depicts a gradient that is associated with an increase in clast density and an increase in skewness (= positive skewness values) of the sediment size distribution towards an excess of finer clast sizes (Fig. 4a, b). No biotic components except for cacti (C) grouped closely with these drivers in the upper part of the plot. Swales, flattened swales and most desert pavement units were associated with these drivers and can be linked to a low abundance of biological components. In contrast, a lower clast density with a coarser-skewed clast distribution, as

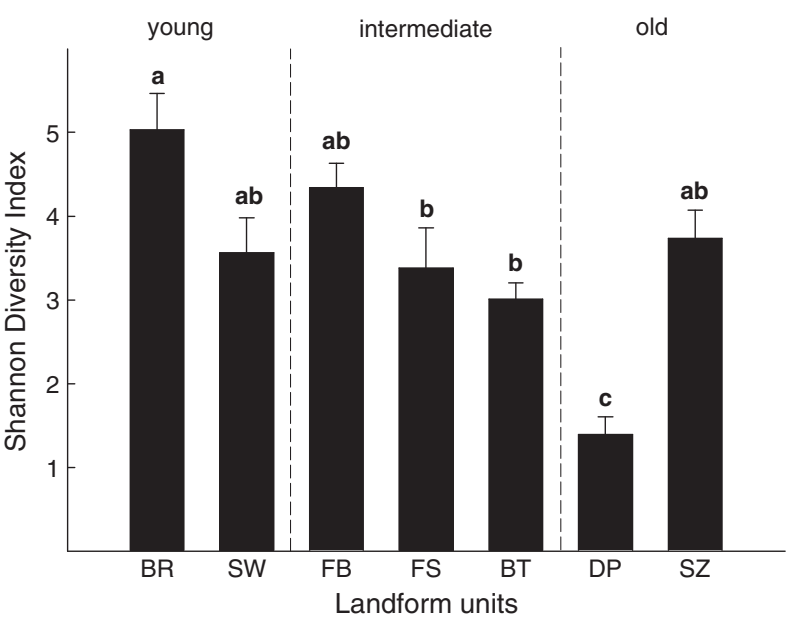

Fig. 3. Bar graph showing Shannon diversity index values of biological soil crust community and plant functional group diversity between the seven landform units. Letters above bars indicate significant difference between landform units.
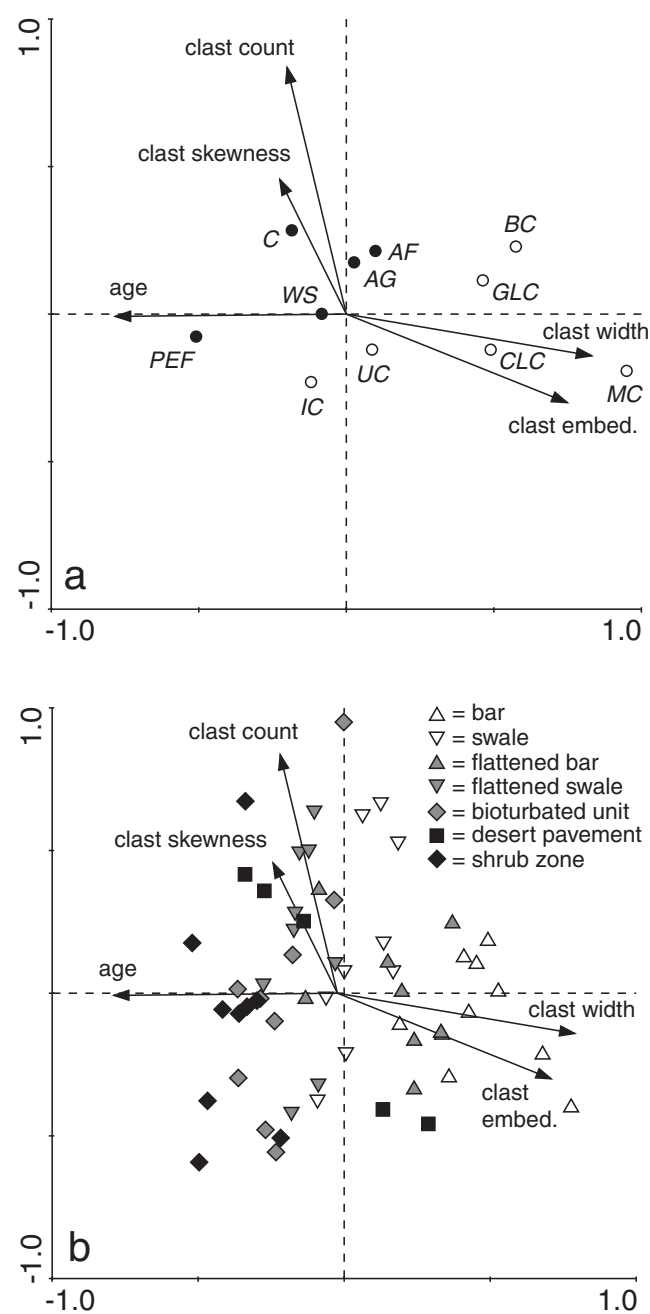

Fig. 4. CCA biplots for (a) biological soil crust communities and plant functional groups (IC = Incipient algal crust, $\mathrm{UC}=$ light algal crust, $\mathrm{BC}=$ dark algal crust, $\mathrm{CLC}=$ cyanolichen crust, $\mathrm{GLC}=$ green algal lichen crust, $\mathrm{MC}=$ moss crust, $\mathrm{AG}=$ annual grasses, $\mathrm{AF}=$ annual forbs, $\mathrm{PEF}=$ perennial forbs, $\mathrm{C}=$ cacti, WS $=$ woody shrubs) and (b) studied landform units. Biplots are showing significant explanatory abiotic variables only. Axis 1 (horizontal) explains $49 \%$ and axis 2 (vertical) explains $18 \%$ of the total variability.

particularly found in bars and flattened bars, are linked to higher abundance of biological soil crusts as they plot in the lower side (Fig. 4a, b). Vascular plants plotted near the origin (Fig. 4a).

\section{Discussion}

\subsection{Landscape structure}

At the meso-scale, the landscape of a Mojave Desert fan skirt contains highly diverse landform units. Moreover, these landform units are associated with distinct assemblages of abiotic and biotic land surface properties. In general, the landform is dominated by abiotic components, with a limited distribution of biotic components. This patchy distribution is similar to the findings of other studies in the Mojave Desert (Johansen et al., 2001; Belnap, 2002; Pietrasiak et al., 2011a,b). However, patchiness of crust and plant distributions showed a consistent pattern within the geomorphic framework and was an important factor in separating the landform units in the combined abiotic and biotic discriminant analysis. Comparable to other sites in the Mojave Desert (Johansen et al., 2001; Belnap et al., 2007; Pietrasiak et al., 2011a,b), algal crust types were dominant. Mosses and lichen crusts were minor components of biological soil crust communities. Vascular plants always had a greater cover than crusts on all landform 
units. Typically, over the course of succession vascular plants have a competitive advantage over biological soil crusts to establish in favorable environments (Belnap et al., 2001).

\subsection{Implications of abiotic and biotic land surface components on geomorphic processes}

Specific assemblages of land surface components and their change over time can impact geomorphic processes differently (Hirmas et al., 2011). The morphological properties of surface rocks, biological soil crusts, and vascular plants have important effects on water and wind flow, sediment production and deposition, and erosion (Descroix et al., 2001; Wainwright, 2009). By using a chronosequence approach we can infer how feedbacks between abiotic and biotic land surface components influence geomorphic processes over time and impact landscape evolution (McAuliffe, 1994).

\subsubsection{Hydrological processes}

Lateral wind and water flow is accelerated at macro- and microscales by flat surfaces such as smooth desert pavements (Wood et al., 2005), cyanobacterial crust (Belnap, 2006), or individual rock surfaces (Warren-Rhodes et al., 2007). Conversely, lateral wind or water flow is slowed by any obstacle, which increases the flow turbulence and tortuosity (Descroix et al., 2001; Belnap, 2006), such as protruding surface clasts (Yair and Klein, 1973), roughened biological soil crust types (Belnap, 2006), and plant canopies and litter (Abrahams and Parsons, 1991; Neave and Abrahams, 2001). Infiltration generally is promoted by biological components, such as animal burrows, plant root channels (Abrahams and Parsons, 1991; Neave and Abrahams, 2001), or macropores formed by certain biological soil crusts (Belnap, 2006). Infiltration can be inhibited by tightly packed clast layers (Wood et al., 2005) or dense cyanobacterial crusts that clog soil pores (Belnap, 2006).

By applying these known hydrological feedbacks to the landform mosaic units investigated in this study, the following patterns of contrasting hydrological processes in this landscape emerge. Bars, and to a lesser degree, flattened bars had rough surfaces due to extensive protruding coarse gravel and cobble cover. They also had some of the most extensive biological soil crust cover and were particularly rich in crust types promoting roughness and consequent water infiltration. Furthermore, substantial numbers of woody shrubs with extensive root systems were present in these areas. Due to the combined effect of their land surface properties, these landform units are sites with increased water infiltration and decreased runoff. In contrast, swales and flattened swales had relatively smooth surfaces due to smaller clast size and lower vegetation and biological soil crust abundance. Infiltration would therefore be lower and the probability of runoff higher. However, infiltration in these sites may still be relatively high due to the low embeddedness of the smaller sized surface gravel, comparable with findings by Herrick et al. (2010). Additionally, once the infiltration capacity of adjacent convex-shaped bars or flattened bars is exceeded, some runoff and debris could be redistributed to concave swales or flattened swales due to gravitational forces. Desert pavement sites were characterized by the highest clast density, lowest vegetation cover, and general absence of crusts. Although clasts were highly embedded, the surface was relatively smooth, as indicated by the lowest microtopography recorded for all landform units. These properties combine to decrease infiltration and increase runoff on desert pavements. In the biologically active bioturbated and shrub zone units, increased infiltration rates can be expected due to preferential water flow in macropores and channels created by the abundant fauna and flora.

\subsubsection{Processes involved in sediment production or trapping}

Sediment and dust can be produced naturally by the burrowing activity of small mammals such as ground squirrels, kangaroo rats or pocket mice, all of which are common rodents in the Mojave Desert
(McAuliffe and McDonald, 2006). On the other hand, sediments and dust can deposit on any object that interferes with wind movement. Consequently, at small spatial extents, sites of deposition and accumulation are crevices between protruding rocks, as well as crevices in rugose or pinnacled biological soil crust types or individual moss and lichen thalli (Belnap, 2006; Hirmas and Graham, 2011). Dust and coarser sediment is also trapped and accumulated around shrubs and grasses, forming mounds (Wainwright, 2009). At a broader spatial extent the topographical rough bar and swale pattern promotes sediment deposition, whereas the tightly packed clasts in surfaces of desert pavements with a smooth microtopography are less efficient in dust trapping (Hirmas et al., 2011).

Thus, due to their roughness index and the microtopography added by vegetation and rugose crusts, the landform units from this study can be ranked in their ability to trap sediment and dust as follows: bars $>$ flattened bars $>$ shrub zones $>$ bioturbated units $>$ swales $>$ flattened swales $>$ desert pavements. Bioturbated and shrub zone units are the most likely sites of sediment production due to the greater burrowing activity of small mammals in these unit types. The sediment can be transported away by wind or runoff water. However, bare soil cover was $<10 \%$ in these units. Gravel, vegetation, and biological soil crusts still covered a considerable portion of the ground despite the natural disturbance, which may help to trap and stabilize the newly produced sediment, as well as allochthonous sediment.

\subsubsection{Erosional processes}

Eolian and fluvial erosional processes are prevented by the presence of surface rocks, biological soil crusts, plant litter and roots (Hupy, 2004; Belnap et al., 2007). Specifically, surface rocks, biological soil crusts, and plant litter cover the land surface, protecting the underlying soil and reducing rill formation and sheet erosion (Valentin and Casenave, 1992) and/or intercepting raindrop splash effects (Descroix et al., 2001; Neave and Abrahams, 2001; Belnap, 2006; Herrick et al., 2010). Also, biological soil crusts and plant roots function to promote soil aggregation and porosity (Neave and Abrahams, 2001; Belnap, 2006; Wainwright, 2009).

Overall, eolian and fluvial erosion on a fan skirt should be minimal due to the gentle inclination of its slope $(1-2 \%)$. Only extreme events such as intense flashfloods may impact this landscape. Also, exposed soil was a minor component of all landform units because the soils are protected by vegetation, crusts or clast cover, and thus, most have a limited erosion potential. Physical crust observed under fine-sized gravel in swale and flattened swale units may also limit erosion. Even a vegetation- and crust-devoid desert pavement has a low erosion potential due to the densely packed gravel and cobble layer that seals the ground and protects the underlying soil.

In bioturbated and shrub zone units, soil stability due to crusts may be limited in the plant interspaces. Soil covered by incipient or light algal crusts is less protective against raindrop splash than lichen and moss crusts in bars and swales (Belnap, 2006). Algae, fungi, and cyanobacteria grow mostly within the soil matrix, leaving parts of the ground surface exposed to raindrop impacts (Belnap, 2006). In contrast, lichen and mosses protrude over the soil and dissipate raindrop impact with their thalli.

\subsection{Implications of geomorphology and linked physical land surface properties on the spatial distribution of biota}

This study distinguished several abiotic land surface properties that drive vascular plant and biological soil crust community components and suggests that different drivers influence these two biological communities. The most important drivers for dark algal, lichen, and moss crust abundance were variables that determine a beneficial microhabitat: a coarse surface rock size with protruding embedded rocks that have soil crevices in between them. These properties were preferentially found in bar units. The abundance of well-developed crusts with 
mosses and lichens can be related to physical properties and suitable habitat conditions (Pietrasiak et al., 2011a,b). Surface rocks may offer a favorable microclimate by decreasing radiation stress and improving availability and amount of moisture (Warren-Rhodes et al., 2007). Improved moisture conditions allow for longer hydration periods of the crusts, which are linked to enhanced carbon and nitrogen fixation (Evans and Johansen, 1999). In addition, roughness created by protruding clasts can aid in dust capture, promoting nutrient status, waterholding capacity, and entrapment of lichen propagules (Belnap, 2002; Lalley and Viles, 2006).

In contrast, as seen in the CCA biplot, older surfaces were associated with communities mainly composed of incipient and light algal crusts. This trend can be linked to an overall decrease in microtopography and clast size, and, to some degree, an increase in clast density over time. These changes in microhabitat may be less favorable for moss and lichen crust establishment, as they provide fewer soil crevices available for their colonization. Some older landforms also were associated with a higher occurrence of small mammal burrowing activity in bioturbation and shrub zone units, which could produce unstable microsites due to natural disturbance by bioturbation.

Greater abundance of some plant functional groups was apparent on older landforms. In particular, the abundance of perennial forbs was greatest in older shrub zone units. However, most of the plant functional groups in the CCA plotted close to the origin, and their abundance could not be fully determined by land surface characteristics. Soil properties and inter- as well as intra-specific interactions may be stronger drivers for plants at this spatial extent. On the other hand, old geomorphic units with increased clast density, finer clast-size distribution, and excess of fine clast sizes (positive skewness) as found in flattened swales and desert pavements impede both biological soil crusts and plants.

Although not measured directly, links to faunal abundance may be inferred from the knowledge of vegetation and crust abundance. For example, kangaroo rats, pocket mice, and ground squirrels, which are the most abundant burrowing rodents in Mojave Desert, prefer large perennial shrubs such as Larrea tridentata and Lycium andersonii (McAuliffe and McDonald, 2006), which were commonly found in our shrub zone units. Presence of small mammals can, in turn, create further surface heterogeneity by creating new habitats and facilitating overall biodiversity of these mosaics (Davidson and Lightfoot, 2008). Bars and swales with abundant moss, lichen, and dark algal crusts may be potential habitats for invertebrates specialized in feeding on these resources (Belnap, 2006; Darby et al., 2007), whereas shrub zone units, which were preferentially associated with light algal crusts, may provide suitable stability for burrows used by small reptiles (Zaady and Bouskila, 2002).

\subsection{Hypothesized landform evolution}

In our study we described the unique and distinct structure of a desert landscape and observed strong ecological and geomorphic links and feedbacks between landform configurations and abiotic and biotic land surface properties. As a result, two distinctively diverging trajectories of landform evolution can be hypothesized, covering a time span of approximately 500 to $10,000-50,000$ years of the arid Holocene (Fig. 5). The first trajectory describes an abiotic landform evolution and the second a biotic pathway (Fig. 5). Both trajectories result in two sharply contrasting oldest states: barren units in the abiotic landform evolution versus units with abundant biotic cover and biodiversity in the biotic evolution (Fig. 5).

The trajectory of an abiotic landform evolution is the development of a young alluvial debris deposit into a desert pavement (Fig. 5). In this trajectory, the landforms change from relatively high topographic surfaces to surfaces with a reduced relief, changing from convex- and concave-shaped bars and swales to intermediate-aged flattened bars and swales to flat and smooth desert pavements (Fig, 5). The positive feedback of relief reduction and associated desert pavement formation occurs due to sediment additions as dust-capture, embedding of clasts, material redistribution due to gravitational and hydrological forces, and long-term geomorphic stability with minor erosion events (McAuliffe and McDonald, 2006). All of these processes smooth surface topography (Birkeland, 1999). The sharp mosaic boundaries between young bar and swale units created by the contrast of surface clast dimensions and roughness diminish over time. Additionally, coarse cobbles and gravel weather into smaller clasts (Sharp and Birman, 1963; Al-Faraj and Harvey, 2000). This process explains the decrease in clast size observed in the progression from bars to flattened bars (Table 1). Clasts from bar units mix into swales causing the slight increase of clast size in flattened swales and the reduction in sorting (an increase in the sorting value (Table 1). Consequently, over time, the sharp unit boundaries disappear and become diffuse. Rock crevices that are especially pronounced in bar units eventually get filled in with weathered surface clast material. Desert pavements on old geomorphic surfaces are ultimately large areas comprised of many historical bar and swale mosaics with negligible relief and closely packed surface clasts that seal the surface. Additionally, in this trajectory vegetation and biological soil crust are impacted negatively, mostly attributed to resource redistribution and surface sealing. Both recede over time from covering a quarter to less than $1 \%$ of the ground.

The second trajectory is a biotic landform evolution - the development of a young alluvial debris deposit with bars and swales to a stage of bioturbation, initialized at intermediate age, to eventually shrub zone units at the oldest age (Fig. 5). The most critical driving forces for this trajectory are positive feedbacks due to biotic interactions and facilitations of flora and fauna through time that result in an alternative future state (Peters et al., 2006). Rietkerk et al. (2004) described this phenomenon as a resource concentrating mechanism that leads to the establishment of self-organized biological patchiness. We hypothesize that at our site, large shrubs and small burrowing mammals function as ecosystem engineers. Large shrubs are preferred habitats for small mammals (McAuliffe and McDonald, 2006). During their foraging and burrowing activities over time, the abiotic processes that produce a tightly packed clast layer are inhibited (Neave and Abrahams, 2001). Newly exposed bare soil and rock interspace crevices are created due to this natural disturbance and become available for crust and vascular plant colonization or redistribution with wind or water. Burrowing activity also may enhance 'shrub islands of fertility' (Gallardo and Schlesinger, 1992; Schlesinger et al., 1996) by promoting soil mixing, accumulating organic matter via feces and seed caches, and increasing infiltration due to increased macroporosity. Moreover, bioturbation encourages redistribution of material and concentration of resources to this spatial patch (Rietkerk et al., 2004; Peters et al., 2006). Expansion of bioturbation units with one large shrub to the shrub zone units with many shrubs (Fig. 5) may result from (1) formation of Larrea clones growing outward (McAuliffe et al., 2007) while simultaneously shifting burrowing mammal activity outward; (2) preferential germination of seeds brought in by small mammals as cache (see Alkon, 1999); and (3) seed trapping by established shrubs and successful seed germination in fertile soils under nurse shrubs. Additionally, due to burrowing activity over long time scales, more bare soil may become available for biological soil crust colonization (Table 2). Mobile and/or ubiquitous cyanobacteria, algae and fungi are pioneer colonizers that quickly can become established on newly exposed soil material and initiate crust formation (see Belnap, 2006). Through time, the shift of burrowing activity outward as well as its concentration under selected shrubs can increase the area of soil in shrub-interspaces for biological soil crust colonization. This soil may be spatially isolated from burrowing disturbance and stable enough for small colonizations of non-mobile lichen and mosses.

\section{Conclusions}

Competition for limited water results in patchy vegetation cover on initial geologic materials in desert ecosystems. Distinctly different 
young geomorphic surface (500-1,000 yrs. old)

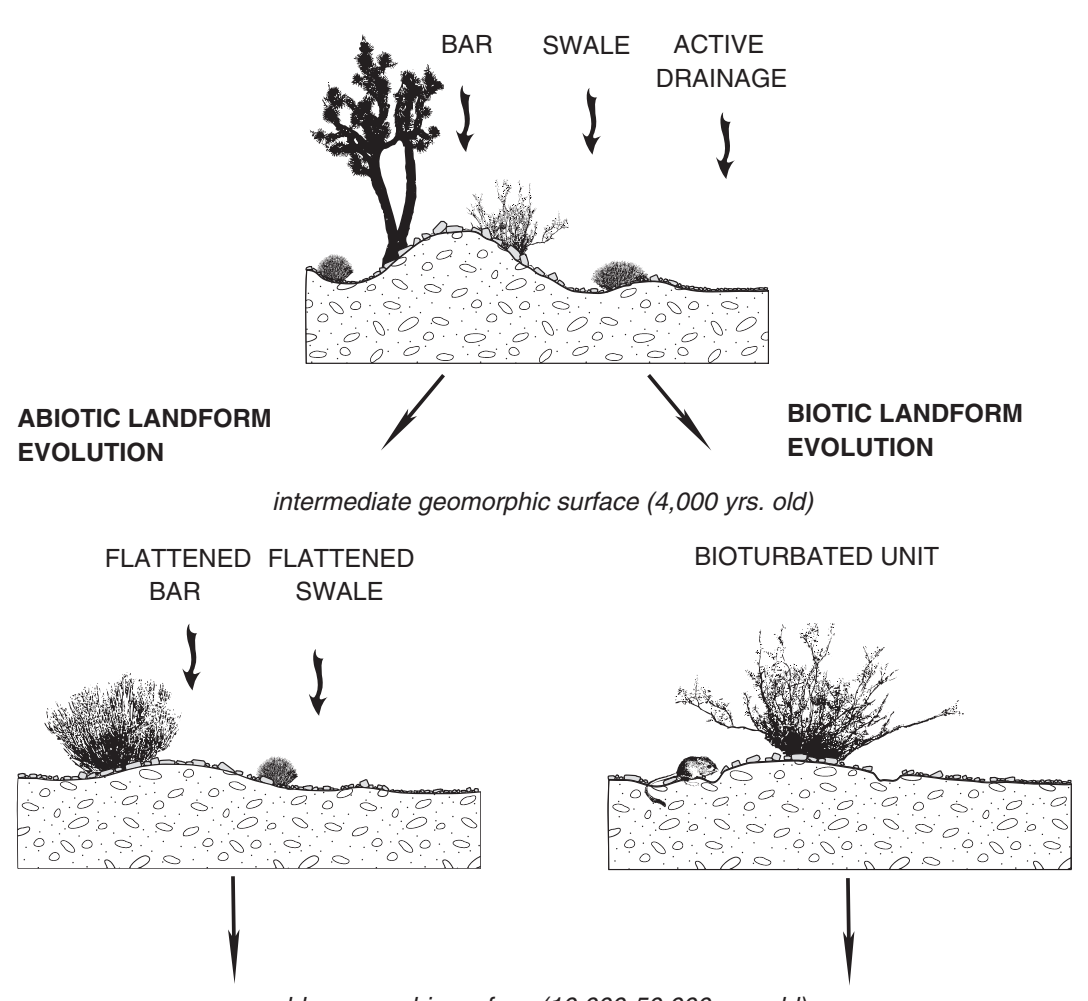

old geomorphic surface $(10,000-50,000$ yrs. old)

DESERT

PAVEMENT

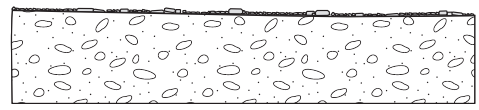

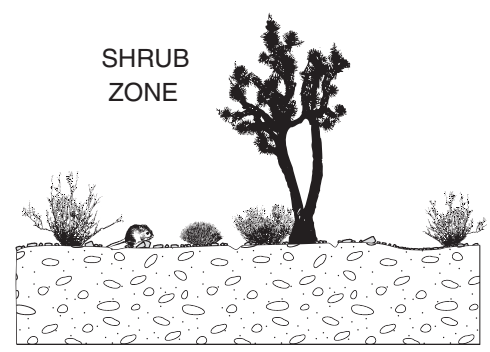

Fig. 5. Hypothesized mechanistic scheme of abiogenic and biogenic landform evolution of a fan skirt in the Mojave Desert. Components not drawn to scale.

environments near perennial shrubs, with associated burrowing fauna, compared to inter-shrub spaces set up divergent processes. Over time, these processes reinforce the differences between vegetated and nonvegetated areas. Thus, linkages and feedbacks between land surface properties and the biota yielded two distinct landform evolutionary trajectories through time. An abiotic trajectory is driven by processes such as relief reduction, dust addition, material redistribution, and desert pavement formation, whereas a biotic trajectory is driven by processes such as bioturbation, shrub-island formation, and inter- and intraspecific facilitation. Our study also demonstrated that landform units with defined land surface characteristics are tightly linked to vascular plant functional group and biological soil crust community diversity and abundance.

Overall, our work indicates how finer-scaled geomorphological studies with an ecological focus can make profound contributions to the understanding of desert biogeomorphology, landscape evolution, and ecology. Our detailed investigation supports theoretical models of self-organized patchiness of arid ecosystems (Rietkerk et al., 2004; Bailey, 2011). Moreover, our experimental data can be used to build more sensitive models, as it combines spatial and temporal dynamics for multiple biotic and abiotic landscape components within a geomorphic framework. Future work should investigate potential links between the abiotic and biotic evolutionary landscape trajectories and soil development and ecosystem functions.

\section{Acknowledgements}

We thank the National Park Service for permission to work within the Mojave National Preserve, especially Debra Hughson for processing the permit applications. We also thank William Duong, Jeffrey Gow, Eric Lee, and Alyssa Tamase for assistance with laboratory and fieldwork. Funding for fieldwork, laboratory analysis, and logistics was provided by the California Desert Research Fund at The Community Foundation serving Riverside, and the Kearney Foundation for Soil Science. Graduate student assistant support was provided by the USDA-NRCS and University of California, Riverside. We would like to thank the anonymous reviewers for their insightful suggestions on the manuscript.

\section{References}

Aanderud, Z.T., Schuldman, M.I., Drenovsky, R.E., Richards, J.H., 2008. Shrub-interspace dynamics alter relationships between microbial community composition and belowground ecosystem characteristics. Soil Biol. Biochem. 40, 2206-2216.

Abrahams, A.D., Parsons, A.J., 1991. Relation between infiltration and stone cover on a semiarid hillslope, Southern Arizona. J. Hydrol. 122, 49-59.

Al-Faraj, A., Harvey, A.M., 2000. Desert pavement characteristics on wadi-terrace and alluvial fan surfaces: Wadi Al-Bih, U.A.E. and Oman. Geomorphology 35, 279-297.

Alkon, P.U., 1999. Microhabitat to landscape impacts: crested porcupine digs in the Negev Desert highlands. J. Arid Environ. 41, 183-202.

Bailey, R.M., 2011. Spatial and temporal signatures of fragility and threshold proximity in modelled semi-arid vegetation. Proc. R. Soc. B 278, 1064-1071. 
Bangert, R.K., Slobodchikoff, C.N., 2000. The Gunnison's prairie dog structures a high desert grassland landscape as a keystone engineer. J. Arid Environ. 46, 357-368.

Bedford, D.R., Small, E.E., 2008. Spatial patterns of ecohydrologic properties on a hillslopealluvial fan transect, central New Mexico. Catena 73, 34-48.

Belnap, J., 2002. Impacts of off-road vehicles on nitrogen cycles in biological soil crusts: resistance in different U.S. deserts. J. Arid Environ. 52, 155-165.

Belnap, J., 2006. The potential roles of biological soil crusts in dryland hydrologic cycles. Hydrol. Process. 20, 3159-3178.

Belnap, J., Kaltenecker, J.H., Rosentreter, R., Williams, J., Leonard, S., Eldridge, D.J., 2001. Biological Soil Crusts: Ecology and Management: TR-1730-2. US Department of the Interior, Denver, CO.

Belnap, J., Phillips, S.L., Herrick, J.E., Johansen, J.R., 2007. Wind erodibility of soils at Fort Irwin, California (Mojave Desert), USA, before and after trampling disturbance: Implications for land management. Earth Surf. Process. Landf. 32, 75-84.

Birkeland, P.W., 1999. Soil and geomorphology, 3rd ed. Oxford University Press, New York, NY.

Bisigato, A.J., Villagra, P.E., Ares, J.O., Rossi, B.E., 2009. Vegetation heterogeneity in Monte Desert ecosystems: a multi-scale approach linking patterns and processes. J. Arid Environ. 73, 182-191.

Bradford, D.F., Neale, A.C., Nash, M.A., Sada, D.W., Jaeger, J.R., 2003. Habitat patch occupancy by toads (Bufo punctatus) in a naturally fragmented desert landscape. Ecology 84, 1012-1023.

Buxbaum, C.A.Z., Vanderbilt, K., 2007. Soil heterogeneity and the distribution of desert and steppe plant species across a desert-grassland ecotone. J. Arid Environ. 69, 617-632.

Crawford, C.S., 1988. Nutrition and habitat selection in desert detritivores. J. Arid Environ. $14,111-121$.

Darby, B.J., Neher, D.A., Belnap, J., 2007. Soil nematode communities are ecologically more mature beneath late- than early-sucessional stage biological soil crusts. Appl. Soil Ecol. 35, 203-212.

Davidson, A.D., Lightfoot, D.C., 2008. Burrowing rodents increase landscape heterogeneity in a desert grassland. J. Arid Environ. 72, 1133-1145.

Descroix, L., Viramontes, D., Vauclin, M., Gonzales Barrios, J.L., Esteves, M., 2001. Influence of soil surface features and vegetation on runoff and erosion in the Western Sierra Madre (Durango, Northwest Mexico). Catena 43, 115-135.

Dixon, J.C., 2009. Aridic soils, patterned ground, and desert pavements, In: Parsons, A.J. Abrahams, A.D. (Eds.), Geomorphology of Desert Environments, 2nd ed. Springe Science and Business Media, New York, NY.

Drenovsky, R.E., Steenwerth, K.L., Jackson, L.E., Scow, K.M., 2010. Land use and climatic factors structure regional patterns in soil microbial communities. Glob. Ecol. Biogeogr. 19, 27-39.

Dunkerly, D.L., Brown, K.J., 1995. Runoff and runon areas in a patterned chenopod shrubland, arid western New South Wales, Australia: characteristics and origin J. Arid Environ. 30, 41-55.

Eghbal, M.K., Southard, R.J., 1993. Micromorphological evidence of polygenesis of 3 Aridisols, Western Mojave Desert, California. Soil Sci. Soc. Am. J. 57, 1041-1050.

El-Bana, M., Abdel-Hameid, K., Van Hecke, P., Bogaert, J., 2002. Vegetation composition of a threatened hypersaline lake (Lake Bardawil), North Sinai. Plant Ecol. 163, 63-75.

Eldridge, D.J., Greene, R.S.B., 1994. Assessment of sediment yield by splash erosion on a semiarid soil with varying cryptogam cover. J. Arid Environ. 26, 221-232.

Eldridge, D.J., Zaady, E., Shachak, M., 2002. Microphytic crusts, shrub patches and water harvesting in the Negev Desert: the Shikim system. Landsc. Ecol. 17, 587-597.

Evans, R.D., Johansen, J.R., 1999. Microbiotic crusts and ecosystem processes. Crit. Rev. Plant Sci. 18, 183-225.

Evenari, M., 1985. Adaptations of plants and animals to the desert environment. In: Evenari, M., Noy-Meir, I., Goodall, D.W. (Eds.), Hot deserts and arid shrublands. vol. 12a. Elsevier Science Publishers, Amsterdam, pp. 79-93.

Fernandez-Gimenez, M., Allen-Diaz, B., 2001. Vegetation change along gradients from water sources in three grazed Mongolian ecosystems. Plant Ecology 157, 101-118.

Folk, R.L., 1980. Petrology of Sedimentary Rocks. Hemphill Publishing Company, Austin, TX.

Gallardo, A., Schlesinger, W.H., 1992. Carbon and nitrogen limitation of soil microbial. Biomass in desert ecosystems. Biogeochemistry 18, 1-17.

Gaston, K.J., Blackburn, T.M., 1999. A critique for macroecology. Oikos 84, 353-368.

Gile, L.H., Gibbens, R.P., Lenz, J.M., 1998. Soil-induced variability in root systems of creosotebush (Larrea tridentata) and tarbush (Flourensia cernua). J. Arid Environ. 39, 57-78.

Ginzburg, O., Whitford, W.G., Steinberger, Y., 2008. Effect of harvester ant (Messor spp.) activity on soil properties and microbial communities in a Negev Desert ecosystem. Biol. Fertil. Soils 45, 165-173.

Goudie, A. 2002. Great Warm Deserts of the World: Landscape and Evolution, 1st ed. Oxford University Press USA, New York, NY.

Gurevitch, J., Scheiner, S.M., Fox, G.L., 2006. The ecology of Plants, 2nd ed. Sinauer Associates, Sunderland, MA.

Gutzwiller, K.J., Barrow Jr., W.C., 2002. Does bird community structure vary with landscape patchiness? A Chihuahuan Desert perspective. Oikos 98, 284-298.

Hall Jr., C.A., 2007. Introduction to the Geology of Southern California and Its Native Plants. University of California Press, Berkeley, CA.

Hamerlynck, E.P., McAuliffe, J.R., McDonald, E.V., Smith, S.D., 2002. Ecological responses of two Mojave Desert shrubs to soil horizon development and soil water dynamics. Ecology 83, 768-779.

Haussmann, N.S., 2011. Biogeomorphology: understanding different research approaches. Earth Surf. Process. Landf. 36, 136-138.

Herrick, J.E., Van Zee, J.W., Belnap, J., Johansen, J.R., Remmenga, M., 2010. Fine gravel controls hydrologic and erodibility responses to trampling disturbance for coarse textured soils with weak cyanobacterial crusts. Catena 83, 119-126.
Hirmas, D.R., Graham, R.C., 2011. Pedogenesis and soil-geomorphic relationships in an arid mountain range, Mojave Desert, California. Soil Sci. Soc. Am. J. 75, 192-206.

Hirmas, D.R., Graham, R.C., Kendrick, K.J., 2011. Soil-geomorphic significance of land surface characteristics in an arid mountain range, Mojave Desert, USA. Catena 87, $408-420$

Hook, P.B., Burke, I.C., 2000. Control by topography, soil texture, and microclimate. Ecology 81, 2686-2703.

Hupy, J.P., 2004. Influence of vegetation cover and crust type on wind-blown sediment in a semi-arid climate. J. Arid Environ. 58, 167-179.

Jannick, N.O., Phillips, F.M., Smith, G.I., Elmore, D., 1991. A Cl-36 chronology of lacustrine sedimentation in the Pleistocene Owens River system. Geol. Soc. Am. Bull. 103, 1146-1159.

Johansen, J.R., Britton, C., Rosati, T.C., Li, X., St. Clair, L.L., Webb, B.L., Kennedy, A.J., Yanko, K.S., 2001. Microbiotic crust of the Mojave Desert: factors influencing distribution and abundance. In: Elster, J., Seckbach, J., Vincent, W.F., Lhotský, O. (Eds.), Algae and extreme environments, Proc. Internat. Conf., Třeboň, Sept. 2000, Nova Hedwigia, Beiheft. , 123, pp. 341-371.

Koehler, P.A., Anderson, R.S., Spaulding, W.G., 2005. Development of vegetation in the Central Mojave Desert of California during the late Quarternary. Palaeogeogr. Palaeoclimatol. Palaeoecol. 215, 297-311.

Lalley, J.S., Viles, H.A., 2006. Do vehicle track disturbances affect the productivity of soilgrowing lichens in a fog desert? Funct. Ecol. 20, 548-556.

Lawton, J.H., 1999. Are there general laws in ecology. Oikos 84, 177-192.

Lepš, J., Šmilauer, P., 2003. Multivariate Analysis of Ecological Data using CANOCO. Cambridge University Press, Cambridge (269 pp.).

Liu, X., Lindemann, W.C., Whitford, W.G., Steiner, R.L., 2000. Microbial diversity and activity of disturbed soil in the northern Chihuahuan Desert. Biol. Fertil. Soils 32, 243-249.

Ludwig. J.A., Bradford, P.W., Breshears, D.D., Tongway, D.J., Imeson, A.C., 2005. Vegetation patches and runoff-erosion as interacting ecohydrological processes in semiarid landscapes. Ecology 86, 288-297.

MacMahon, J.A., Wagner, F.H., 1985. The Mohave, Sonoran, and Chihuahuan deserts of North America. In: Evenari, M., Noy-Meir, I., Goodall, D.W. (Eds.), Hot deserts and arid shrublands. , vol. 12a. Elsevier Science Publishers, Amsterdam, pp. 105-202.

Mauchamp, A., Montaña, C., Lepart, J., Rambal, S., 1993. Ecotone dependent recruitment of a desert shrub, Flourensia cernua, in vegetation stripes. Oikos 68, 107-116.

McAuliffe, J.R., 1994. Landscape evolution, soil formation, and ecological patterns andprocesses in Sonoran Desert Bajadas. Ecol. Monogr. 64, 111-148.

McAuliffe, J.R., McDonald, E.V., 2006. Holocene environmental change and vegetation contraction in the Sonoran Desert. Quarternary Res. 65, 204-215.

McAuliffe, J.R., Hamerlynck, E.P., Eppes, M.C., 2007. Landscape dynamics fostering the development and persistence of long-lived creosotebush (Larrea tridentata) clones in the Mojave Desert. J. Arid Environ. 69, 96-126.

Miles, S.R., Goudey, C.B., 1997. Ecological Subregions of California: Section and Subsection Descriptions. USDA Forest Service, Pacific Southwest Publication R5-EM TP-005, San Francisco, CA.

Naylor, L.A., Viles, H.A., Carter, N.E.A., 2002. Biogeomorphology revisited: looking towards the future. Geomorphology 47, 3-14.

Neave, M., Abrahams, A.D., 2001. Impact of small mammal disturbances on sediment yield from grassland and shrubland ecosystems in the Chihuahuan Desert. Catena 44, 285-303.

Norris, R.M., Webb, R.W., 1990. Geology of California. John Wiley and Sons Inc., Somerset, NJ.

Osborn, H.B., 1983. Timing and duration of high rainfall rates in southwestern United States. Water Resour. Res. 19, 1036-1042.

Parker, K.C., 1991. Topography, substrate, and vegetation patterns in the northern Sonoran Desert. J. Biogeogr. 18, 151-163.

Parker, K.C., 1995. Effects of complex geomorphic history on soil and vegetation patterns on arid alluvial fans. J. Arid Environ. 30, 19-39.

Peters, D.P.C., Bestelmeyer, B.T., Herrick, J.E., Fredrickson, E.L., Monger, H.C., Havstad, K.M., 2006. Disentangling complex landscapes: new insights into arid and semiarid system dynamics. Bioscience 56, 491-501.

Peterson, F.F., 1981. Landforms of the basin and range province defined for soil survey. Nevada Agricultural Experiment Station Technical Bulletin 28. University of Nevada, Reno.

Pietrasiak, N., 2012. Effects of land surface characteristics on pedogenesis, biological soil crust community diversity, and ecosystem functions in a Mojave Desert piedmont landscape. Ph.D. dissertation. University of California, Riverside (208 pp.)

Pietrasiak, N., Johansen, J.R., Drenovsky, R.E., 2011a. Geologic composition influences distribution of microbiotic crusts in the Mojave and Colorado Deserts at the regional scale. Soil Biol. Biochem. 43, 967-974.

Pietrasiak, N., Johansen, J.R., LaDoux, T., Graham, R.C., 2011b. Spatial distribution and comparison of disturbance impacts to microbiotic soil crust in the Little San Bernardino Mountains of Joshua Tree National Park, California. West. N. Am. Nat. $71,539-552$

Pietrasiak, N., Regus, J.U., Johansen, J.R., Lam, D., Sachs, J.L., 2013. Biological soil crust community types differ in key ecological functions. Soil Biol. Biochem. 65, 168-171.

Rietkerk, M., Dekker, S.C., de Ruiter, P.C., van de Koppel, J., 2004. Self-organized patchiness and catastrophic shifts in ecosystems. Science 30, 1926-1929.

Rostagno, C.M., 1989. Infiltration and sediment production as affected by soil surface conditions in a shrubland of Patagonia, Argentina. J. Range Manag. 42, 382-385.

Saleh, A., 1993. Soil roughness measurement: chain method. J. Soil Water Conserv. 48, 527-529.

Schlesinger, W.H., Raikes, J.A. Hartley, A.E., Cross, A.F., 1996. On the spatial. Patterns of soil nutrients in desert ecosystems. Ecology 77, 364-374. 
Schmidt, K.M., McMackin, M., 2006. Preliminary surficial geologic map of the Mesquite Lake $30^{\prime} \times 60^{\prime}$ quadrangle. California and Nevada: U.S. Geological Survey Open-File Report 2006-1035

Schoeneberger, P.J., Wysocki, D.A., Benham, E.C., Broderson, W.D., 2002. Fieldbook for describing and sampling soils. Version 2.0. Natural Resources Conservation Service.National Soil Survey Center, Lincoln, NE.

Schooley, R.L., Wiens, J.A., 2001. Dispersion of kangaroo rat mounds at multiple scales in New Mexico, USA. Landsc. Ecol. 16, 267-277.

Sharp, R.P., Birman, J.H., 1963. Additions to classical sequence of Pleistocene glaciations, Sierra Nevada, California. Geol. Soc. Am. Bull. 74, 1079-1086.

Sponseller, R.A., Fisher, S.G., 2006. Drainage size, stream intermittency, and ecosystem function in a Sonoran Desert Landscape. Ecosystems 9, 344-356.

Tabachnik, B.G., Fidell, L.S., 2007. Using Multivariate Statistics, 4th ed. Pearson Education, Inc., Boston, MA.

Turk, J., 2012. Vesicular horizon distribution, properties, and pedogenic processes in deserts of the Western United States. (Ph.D. dissertation) University of California, Riverside (196 pp.).

Valentin, C., Casenave, A., 1992. Infiltration into sealed soils as influenced by gravel cover. Soil Sci. Soc. Am. J. 56, 1667-1673.

Viles, H.A., 1988. Introduction. In: Viles, H.A. (Ed.), Biogeomorphology. Blackwell, Oxford, pp. 1-8.
Wainwright, J., 2009. Desert ecogeomorphology, In: Parsons, A.J., Abrahams, A.D. (Eds.), Geomorphology of Desert Environments, 2nd ed. Springer Science and Business Media, New York, NY.

Walker, J.D., Burchfiel, B.C., Davis, G.A., 1995. New age controls on initiation andtiming of foreland belt thrusting in the Clark Mountains, southern California. GSA Bull. 107, $742-750$.

Warren-Rhodes, K.A., Rhodes, K.L., Ng Boyle, L., Pointing, S.B., Chen, Y., Liu, S., Zhuo, P., McKay, C.P., 2007. Cyanobacterial ecology across environmental gradients and spatial scales in China's hot and cold deserts. FEMS Microbiol. Ecol. 61, 470-482.

Watchman, A.L., Twidale, C.R., 2002. Relative and 'absolute' dating of land surfaces. EarthSci. Rev. 58, 1-49.

Wiens, J.A., Stenseth, N.C., Horne, Van, Ims, R.A., 1993. Ecological mechanisms and landscape ecology. Oikos 66, 369-380.

Wood, Y.A., Graham, R.C., Wells, S.G., 2005. Surface control of desert pavement pedologic process and landscape function, Cima Volcanic field, Mojave Desert, California. Catena 59, 205-230.

Yair, A., Klein, M., 1973. The influence of surface properties on flow and erosion processes on debris covered slopes in an arid area. Catena 1,1-18.

Zaady, E., Bouskila, A., 2002. Lizard burrows association with successional stages of biological soil crusts in an arid sandy region. J. Arid Environ. 50, 235-246. 